\title{
4. CALIBRATION OF MIOCENE NANNOFOSSIL EVENTS TO ORBITALLY TUNED CYCLOSTRATIGRAPHIES FROM CEARA RISE ${ }^{1}$
}

\author{
Jan Backman ${ }^{2}$ and Isabella Raffi ${ }^{3}$
}

\begin{abstract}
Ocean Drilling Program Site 926 sediments are well suited to serve as a reference section for calcareous nannofossil biostratigraphy from the low-latitude Atlantic Ocean in the 0- to 14-Ma time interval. Reasons include completeness in deposition and recovery, superbly resolved orbitally tuned chronologic control, generally good carbonate preservation, and the fact that this site represents a location where much evolution evidently occurred. Thirty-four nannofossil events, from the top of Ceratolithus acutus to the top of Sphenolithus heteromorphus, have been investigated at 10-cm sample resolution (averaging 6 k.y.) in over 1400 samples from the earliest Pliocene (5.046 Ma) to the middle Miocene (13.523 Ma). These 34 events have been determined with an average chronological precision of \pm 7 k.y.

This study emphasizes (1) the importance of quantitative approaches to determine time-dependent abundance variation of species to improve the understanding of paleoecologic responses of biostratigraphically useful species to variable and changing paleoenvironmental conditions; and (2) the importance of determining the smallest meaningful sampling interval to capture the finest details of the records of evolutionary emergence or extinction of species that are preserved in cores.
\end{abstract}

\section{INTRODUCTION}

Biostratigraphic zonal schemes based on calcareous plankton groups were well established by the time the Deep Sea Drilling Project (DSDP) began in 1968 (e.g., Stradner, 1959; Bramlette and Sullivan, 1961; Bolli, 1966). From the very beginning of ocean drilling, biostratigraphy has provided an essential tool for dating not only the sedimentary sequences, but also the underlying crust that was reached at many sites. The most famous example is probably DSDP Leg 3 (Maxwell, Von Herzen, et al., 1970), during which the hypothesis of plate tectonics was confirmed by ocean drilling and biostratigraphic dating. Nearly three decades later, biostratigraphy still remains a key tool for dating of marine sediments, simply because other dating tools are often not applicable. In cases where magneto- and cyclostratigraphies are available, these dating tools still depend on biostratigraphy for identification of polarity zones or cycle numbers.

Magnetostratigraphy was not obtained from Leg 154 sediments because of strong drilling-induced overprint, and the dating of these sediments thus relied on calcareous nannofossil and planktonic foraminifer biostratigraphy (Curry, Shackleton, Richter, et al., 1995). The shipboard work on calcareous nannofossils was based on approximately 3000 smear slides, yielding an average sample spacing of less than $2 \mathrm{~m}$. The majority of the nannofossil events, however, were determined to intervals shorter than $1 \mathrm{~m}$, and the task of nannofossil biostratigraphic dating of Leg 154 sediments was largely accomplished aboard ship.

Leg 154 sediments are characterized by cyclic lithological variation, as documented by highly resolved color reflectance and magnetic susceptibility measurements. The cyclo- and biostratigraphies established aboard thus allowed accurate reconstruction of stratigraph-

${ }^{1}$ Shackleton, N.J., Curry, W.B., Richter, C., and Bralower, T.J. (Eds.), 1997. Proc. ODP, Sci. Results, 154: College Station, TX (Ocean Drilling Program).

${ }^{2}$ Department of Geology and Geochemistry, Stockholm University, S-106 91 Stockholm, Sweden.jbackman@geo.su.se

${ }^{3}$ Facoltá di Scienze MM.FF.NN., Universitá "G. d'Annuzio," Campus Universitario Madonna della Piane, Via dei Vestini 31, I-66013 Chieti Scalo, Italy. ically continuous sampling sections for the Pliocene/Pleistocene and large portions of the Miocene at several sites.

High-resolution time control has been established for approximately the past 14 m.y. through astronomical calibration (Shackleton and Crowhurst, this volume), making the Ceara Rise material ideally suited for detailed biostratigraphic studies in an oceanic region where many evolutionary transitions are observed in the fossil record on calcareous nannofossils.

The newly developed time scale of Shackleton and Crowhurst (this volume) was primarily based on Site 926 . They used the following steps. First, an age model was derived from the shipboard biostratigraphy. Second, a time scale was calibrated, working back in time from $5 \mathrm{Ma}$, by matching the magnetic susceptibility variations in the composite depth section to the orbital insolation record of Laskar et al. (1993). Finally, they retuned the sequence of cores from the individual holes of Site 926 and conducted statistical evaluations. Thus, they successfully correlated the lithological cyclicity observed at Site 926 to the astronomically determined variations in Northern Hemisphere summer insolation.

Recent advances in nannofossil biostratigraphy have adopted a strategy that combines quantitative data gathering techniques with short sample spacing intervals, resulting in high-resolution calibration between nannofossil events and cyclostratigraphies, notably from Pleistocene and Pliocene $\delta^{18} \mathrm{O}$ records (e.g., Thierstein et al., 1977; Backman and Shackleton, 1983; Raffi et al., 1993). The present study was based on a continuous and astronomically tuned Miocene stratigraphic sequence extending to about $14 \mathrm{Ma}$ from the western equatorial Atlantic Ocean, and was focused on the following three topics: (1) acquisition of quantitative data of biostratigraphically useful middle and late Miocene nannofossils at 10-cm sample intervals from the composite depth section of Site 926; (2) calibration of the bioevents to the established astrochronology; and (3) comparison with some of the biomagnetochronologic results obtained from Leg 138 sediments in the eastern equatorial Pacific Ocean. Over 1400 samples in the interval from about $153 \mathrm{~m}$ composite depth (mcd) to about 296 mcd were counted, representing the time interval from about 4.98 to $13.61 \mathrm{Ma}$ and yielding an average sample resolution of $6 \mathrm{k} . \mathrm{y}$. 


\section{METHODS}

Deep-sea biostratigraphic analyses are based largely on the presence and absence of species in samples. The predominant way to present the results of such observations is conducted in range chart plots. Quantitative assemblage analysis at $10-\mathrm{cm}$ sample resolution is exceedingly time consuming if longer periods of time are analyzed, which explains why range charts typically present low-resolution data and why the range chart method can be viewed as a rather coarse tool, in terms of resolution, for describing biostratigraphy. Moreover, the qualitative character of range charts implies that potentially useful biostratigraphic information is lost because some bioevents (e.g., those based on abundance relationships) can be recognized only through quantification. The value of range charts lies in that they provide information on lower resolution diversity relationships and biostratigraphy. The range chart method does not fulfill the purposes of the present study, however, and is not applied here.

Experienced biostratigraphers commonly gather accurate biostratigraphic information using qualitative presence-absence data. Such data, however, represent an amalgamation of judgments involving taxonomic perception and abundance that, in turn, depends on such factors as productivity rate and preservation state. It follows that independent judgments of the characters that determine the quality of the bioevents are difficult to achieve from qualitative presenceabsence data. Gathering of quantitative data under defined conditions would considerably open up the biostratigraphic black box, and this becomes particularly important when introducing new or revised age estimates of bioevents.

The quantitative nannofossil data presented here were gathered using the counting technique of Backman and Shackleton (1983), which has been shown to generate reproducible results from a series of duplicate counts and subsamples (e.g., Monechi et al., 1985; Chepstow-Lusty, 1990; Gard and Backman, 1990). We normally counted 25 fields of view, where each field contained an average of about 100-150 nannofossil specimens, or a total of approximately 2500 4000 specimens. The number of view-fields counted were doubled in many critical intervals. The counts were calculated to represent the number of specimens per unit area of the smear slide to compensate for the use of different light microscopes, different magnifications, and hence different view-field diameters, or differences in total area counted. Finally, the quantitative approach also has an advantage in that it provides another class of biostratigraphically useful events (Thierstein et al., 1977), namely, those that are based on consistent changes in proportion between species.

Several analytical fields in paleoceanography, including those using paleoenvironmental proxies such as carbonate concentration or stable isotope ratios, routinely use sampling intervals that are close enough to capture the finest details of the records of environmental change that are preserved in cores. Marine biostratigraphic work, in contrast, has rarely adopted the smallest meaningful sampling interval to acquire its basic information about the evolutionary emergence or extinction of species. When a species is considered to become extinct at a certain stratigraphic level, for example, we are essentially addressing the question of how to determine its final decline in productivity from some given value to zero. One may document the final productivity decline by means of the time-dependent change in abundance. Investigations of the abundance behavior of species require quantitative data combined with short sample-spacing distances and allow us to determine which events are biostratigraphically useful. The effect of sample resolution is demonstrated in Figure 1, which shows that a sample resolution of 650 k.y. (1 sample/core), or of 200 k.y. (3 samples/core), does not contain any of the higher frequency variability revealed by the 8-k.y. sampling (95 samples/core). Short sample-spacing distances allow more precise biostratigraphic and sedimentation rate estimates.

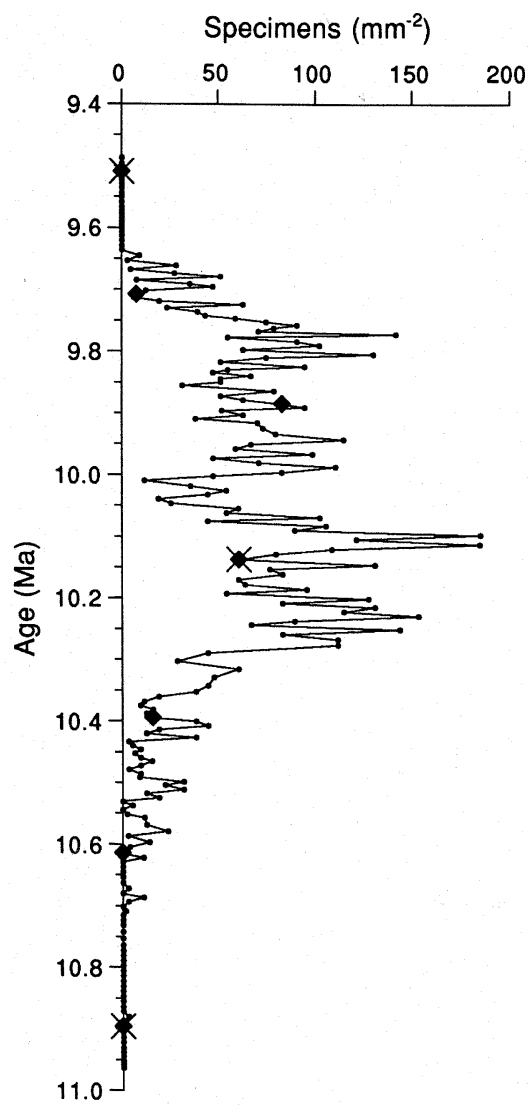

Figure 1. Effects of sample resolution. Catinaster calyculus from Site 926 is shown at $0.1-\mathrm{m}$ sampling intervals ( 1 sample/8 k.y.), displaying considerable short-term variations in abundance (small solid circles). Large crosses represent a 9.5-m sampling interval (1 sample/650 k.y.) and large filled diamonds represent a 3.0-m sampling interval (1 sample/200 k.y.).

The ultimate chronologic precision by which a bioevent can be determined depends chiefly on the independent calibration tool used and how well that tool, or time scale, reflects the true progress of time. Magnetostratigraphy has been the key technique for age calibration of Cenozoic deep-sea biostratigraphic events. But magnetostratigraphy offers no control on sedimentation rate variations within individual polarity zones. Therefore, the accuracy of biostratigraphic age estimates within such zones are dependent on such factors as the duration of the polarity zone and the distance of the bioevent to the nearest reversal boundary. As a result, age calibrations of Cenozoic bioevents have uncertainties on the order of one to a few hundred thousand years. The introduction of orbitally tuned time scales has resulted in huge improvements of age calibrations of such bioevents (Raffi et al., 1993; Shackleton et al., 1995a). As shown below, the 34 age estimates of the Miocene bioevents determined from Site 926 have uncertainties ranging from \pm 2 to \pm 28 k.y., with an average of \pm 7 k.y. Uncertainties are calculated from the sample interval over which the event is constrained (Table 1). This implies that our bioevents are determined with an average chronological precision of $\pm 7 \mathrm{k} . \mathrm{y}$. throughout the 5- to 14-Ma interval investigated here, assuming that Shackleton and Crowhurst's (this volume) orbitally tuned time scale is correct. Moreover, this level of chronological resolution provides a way to evaluate the degree of synchrony of individual bioevents, one of the ubiquitous problems in deep-sea biostratigraphy, in more detail than ever before.

Species abundances in this study are plotted together with the magnetic susceptibility data collected aboard ship, using the time 
scale of Shackleton and Crowhurst (this volume). The susceptibility curves show the dominant influence of the precession and obliquity cycles on the sedimentation and thus the precise chronological control in the study material, despite the lack of magnetostratigraphy. The magnetic susceptibility scale is consistently inverted to give a sense of calcium carbonate variations in the sediment.

Finally, evolutionary trends and the taxonomy of the middle and late Miocene nannofossils discussed below will be presented elsewhere.

\section{BIOSTRATIGRAPHY OF SITE 926}

\section{Events Around the Miocene/Pliocene Boundary}

The change from brackish water Arenazzolo sediments to openmarine sediments in the overlying Trubi marls at Capo Rossello are used to define the Miocene/Pliocene boundary (e.g., Cita, 1975; Channell et al., 1988; Hilgen, 1991). In terms of magnetostratigraphy, the base of the Trubi marls falls within Chron C3r, in accordance with Hilgen's (1991) astronomically calibrated age of 5.32 Ma for the boundary. Rio et al. (1990) used the base of Ceratolithus acutus to approximate the Miocene/Pliocene boundary, whereas Curry, Shackleton, Richter, et al. (1995) placed the boundary between the top of Discoaster quinqueramus and the base of Ceratolithus acutus. The youngest bioevents investigated here belong to the early Pliocene, therefore.

\section{Top of Ceratolithus acutus and Base of Ceratolithus rugosus}

Members of the horseshoe-shaped genera Ceratolithus and Amaurolithus represent minor components of the total nannofossil assemblages at Site 926 and comprise only $0.1 \%-1.0 \%$ of the total assemblage in most samples. Ceratolithus rugosus evolved from Ceratolithus acutus (Gartner and Bukry, 1975), and the base of C. rugosus and the top of $C$. acutus are well-established bioevents in the lowermost Pliocene (Martini, 1971; Bukry, 1973). Abundance data for these species in Site 926 are shown in Figure 2. A short overlap in range is evident. Taking into account the higher abundances of both taxa where they overlap and the fact that some of the forms observed tend to grade into each other in terms of morphology, it appears that the crossover in abundance provides a more easily recognized event than either the base of $C$. rugosus or the top of $C$. acutus. A similar conclusion was derived in a study of Core V28-185 in the central equatorial Pacific (Backman and Shackleton, 1983). They placed the abundance crossover of these species in uppermost Thvera (Chron C3n.4n) at an age that is less than 50 k.y. different from Site 926, if using modern age estimates of the Thvera reversal boundaries (Hilgen et al., 1995). This slight disparity results from the condensed nature of Core V28-185 and large sample spacing in that core (i.e., $19 \mathrm{~cm}$ between the two critical samples).

We noticed that $C$. rugosus was represented by smaller specimens with more slender horns during the earliest part of its range. Measurements of the total length and width of 25 individuals in two typical samples yielded mean length/width relationships of 9.2/6.5 $\mu \mathrm{m}$ at 5.067 Ma and $11.9 / 8.7 \mu \mathrm{m}$ at $4.985 \mathrm{Ma}$, corresponding to a $23 \%-$ $25 \%$ size increase. Furthermore, C. acutus was represented by specimens showing a range of birefringence intensity. There was no easily discernible morphological difference among specimens showing these contrasting optical behaviors, and they are grouped as $C$. acutus in plots (Fig. 2).

A few specimens resembling Ceratolithus armatus were observed in one sample, but they are considered to be morphological endmembers of $C$. acutus. A few specimens resembling Ceratolithus separatus were observed in a few samples from the lower part of the range of $C$. rugosus. The rare and sporadic occurrences of $C$. separa-

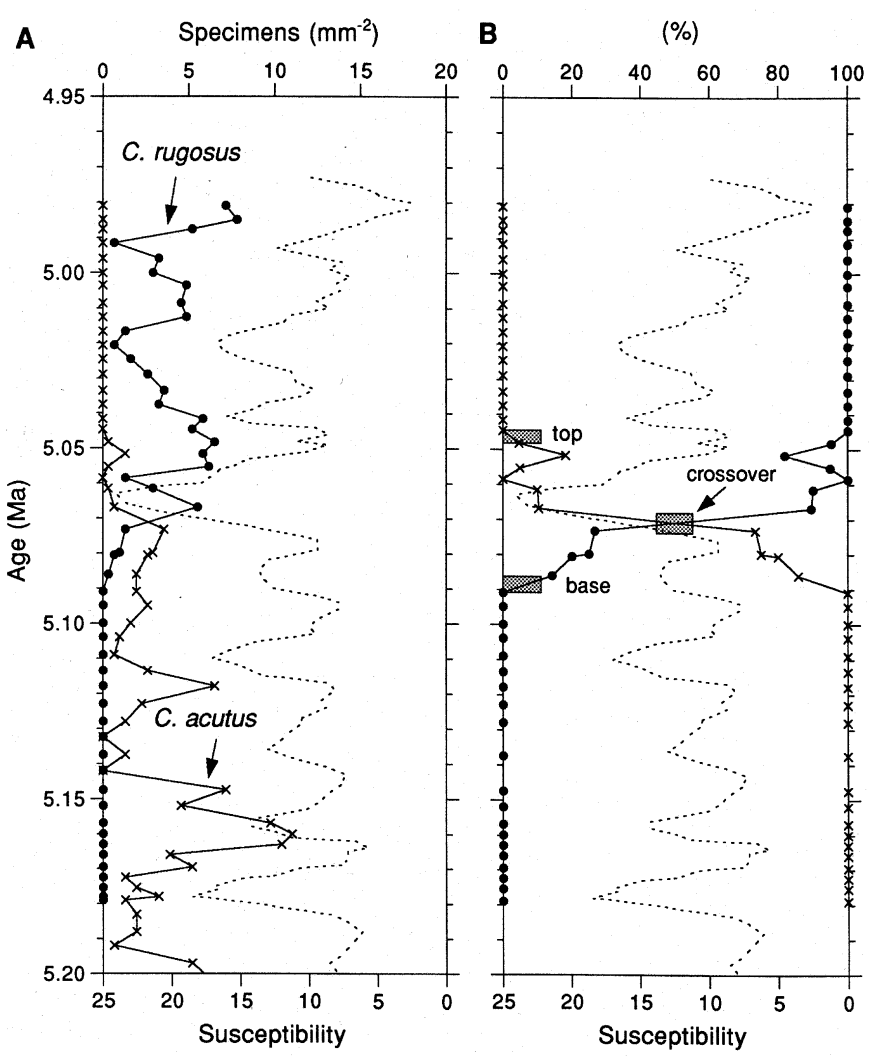

Figure 2. Abundances of Ceratolithus rugosus and Ceratolithus acutus, Site 926. A. Number of specimens per unit area counted $\left(\mathrm{mm}^{-2}\right)$. B. Relative abundance of the two species. Figure $2 \mathrm{~B}$ also shows position and age uncertainty (Table 1; relative width of shaded boxes) of the top of $C$. acutus, the base of $C$. rugosus, and the crossover in abundance. Dotted lines represent magnetic susceptibility values. Increased susceptibility values imply decreased carbonate contents and vice versa. The susceptibility cyclicity reflects precession cycles.

tus, and the presence of forms transitional between the $C$. rugosus and the $C$. separatus morphotypes in these samples, may suggest that the latter represents an end-member morphology that can be contained within a broader $C$. rugosus taxonomic concept. The rarely reported C. separatus was first described from Site 395 at $23^{\circ} \mathrm{N}$ in the central Atlantic, not far from the Ceara Rise (Bukry, 1979).

\section{Base of Ceratolithus acutus and Ranges of Ceratolithus atlanti- cus and Ceratolithus sp. 1}

The total range of $C$. acutus is shown with the total ranges of two other ceratolith morphotypes, Ceratolithus atlanticus and Ceratolithus sp. 1, in Figure 3. The rarely reported C. atlanticus was described from the spot-cored Site 354 at Ceara Rise by Perch-Nielsen (1977, pl. 3). This species is here shown to have a distinct short range that actually straddles the Miocene/Pliocene boundary based on Hilgen's (1991) age estimate of 5.32 Ma for that boundary. This age estimate also indicates that $C$. acutus appeared within the very latest Miocene, about 50 k.y. before the Miocene/Pliocene boundary, and C. atlanticus about $80 \mathrm{k} . \mathrm{y}$. before the boundary. A conspicuous morphotype, Ceratolithus sp. 1, appeared and disappeared within the range of C. atlanticus (Fig. 3). Ceratolithus sp. 1 includes both birefringent and nonbirefringent $\mathrm{Y}$-shaped forms with two long slender, symmetrically arranged horns and often a neatly tapering apical point that may be extended into a rod-shaped feature. The latitudinal distri- 
A

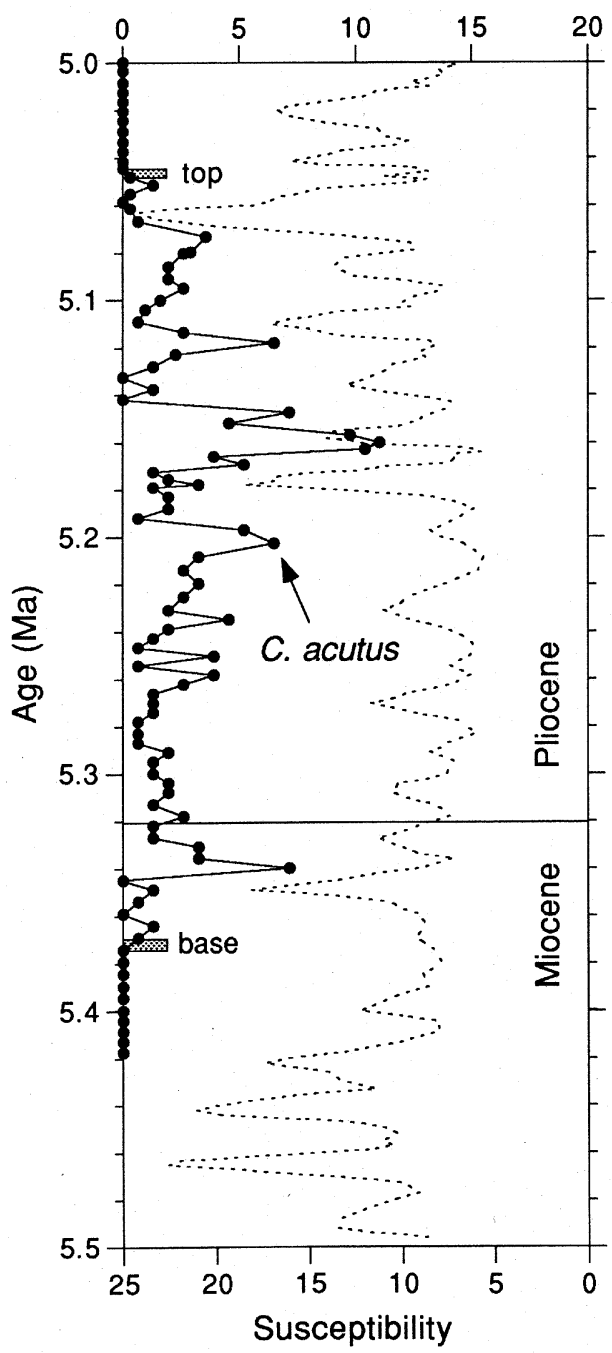

B

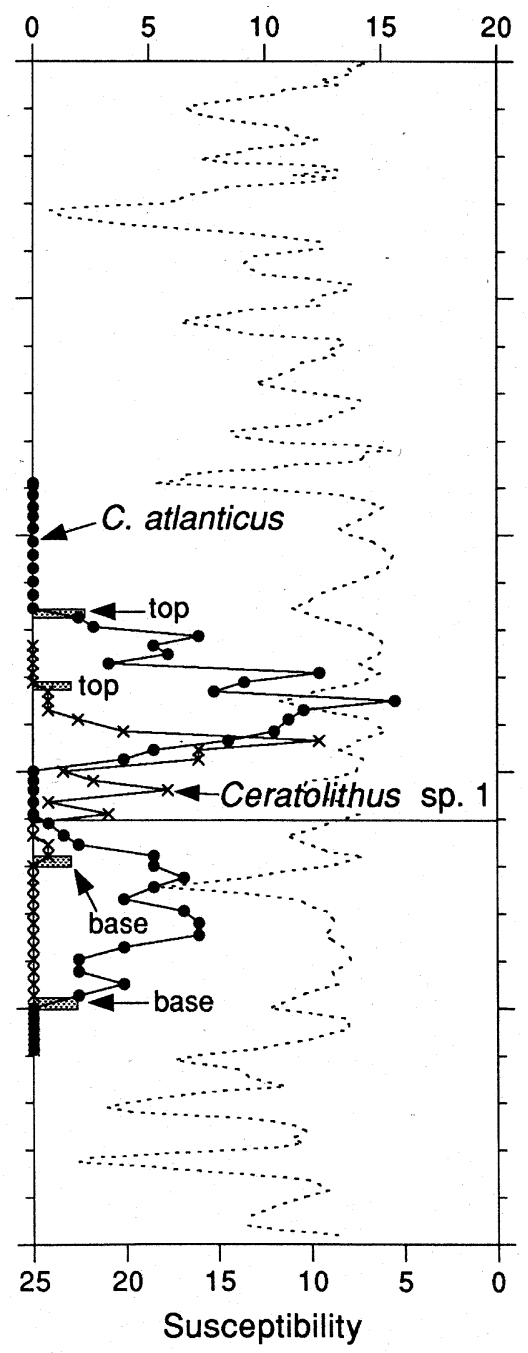

C

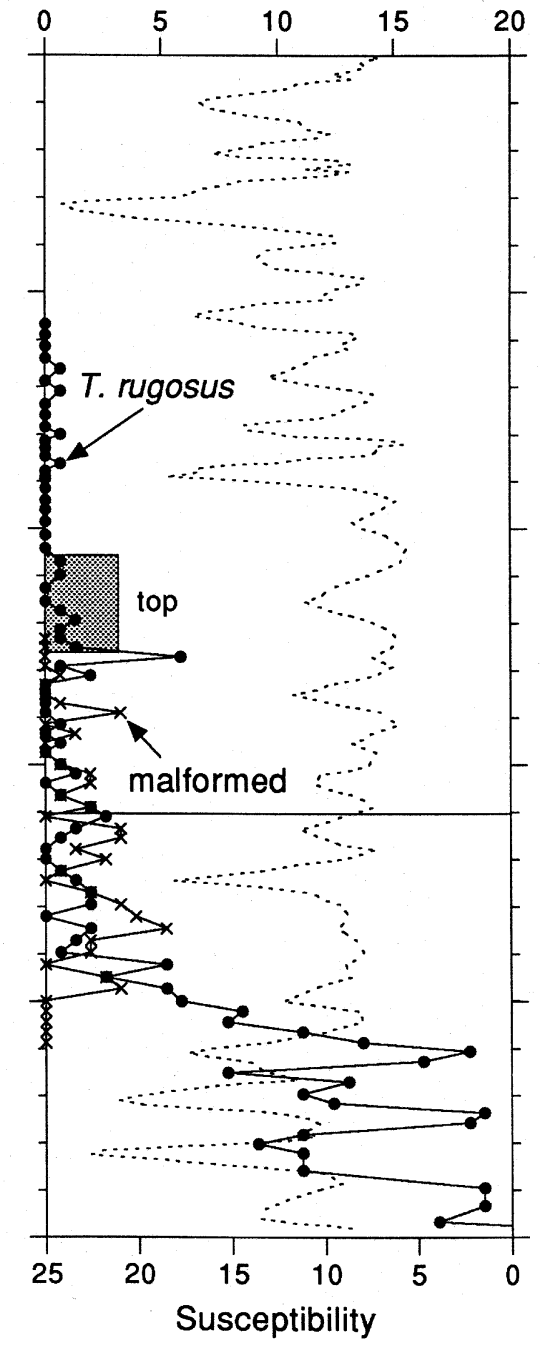

Figure 3. Abundances of (A) Ceratolithus acutus, (B) Ceratolithus atlanticus and Ceratolithus sp. 1, and (C) Triquetrorhabdulus rugosus and malformed specimens of T. rugosus, Site 926. See also explanation in Figure 2.

bution of $C$. atlanticus and Ceratolithus sp. 1 is largely unknown, but it is probably limited to tropical areas considering the general lack of reported occurrences. It follows that the base of the more widely distributed C. acutus represents the best approximation of the Miocene/ Pliocene boundary.

\section{Top of Triquetrorhabdulus rugosus}

The uppermost range of Triquetrorhabdulus rugosus is also plotted in Figure 3. The final range of T. rugosus is characterized by low abundances and the presence of malformed morphotypes, some of which tended to grade into ceratolith morphology. One sample even contained a few $T$. rugosus morphotypes showing birefringence. There is probably an evolutionary explanation to the fact that the final distinct decrease in abundance of $T$. rugosus occurred together with the emergence of malformed specimens of $C$. atlanticus, and subsequently, of $C$. acutus. Forms that we refer to as malformed morphotypes of T. rugosus have been described as two separate species (Triquetrorhabudulus extensus and Triquetrorhabudulus finifer) by Theodoridis (1984), from around the Miocene/Pliocene boundary in the tropical Indian Ocean.

\section{Late Miocene Events}

\section{Top of Discoaster quinqueramus}

The final part of the range of Discoaster quinqueramus is shown in Figure 4. A sharp drop in abundance at about 5.56 Ma is followed by a short series of low abundance values: 19.4, 22.9, 12.3 and 1.8 $\left(\mathrm{mm}^{-2}\right.$; equals one observed specimen in this case). The interval shows no coring disturbance (Curry, Shackleton, Richter, et al., 1995), which may suggest that this low-abundance, 40-cm-thick interval can represent an indigenous occurrence and thus a true but strongly reduced productivity. Furthermore, if the final abundance pattern would be caused by sediment homogenization through bioturbation, it may be assumed that the transition from high abundance values to the zero value would have been smoother. For these reasons, the extinction level has been tentatively placed between the 0.0 and $12.3 \mathrm{~mm}^{-2}$ values, at an age of $5.537 \mathrm{Ma} \pm 5 \mathrm{k} . \mathrm{y}$. We do not exclude, however, the possibility that the extinction occurred $22 \mathrm{k} . \mathrm{y}$. earlier at 5.559 Ma $\pm 3 \mathrm{k} . \mathrm{y}$., during the final sharp abundance decline. Nevertheless, this event clearly occurred during the latest part of the late Miocene, 220-240 k.y. before the Miocene/Pliocene boundary. 


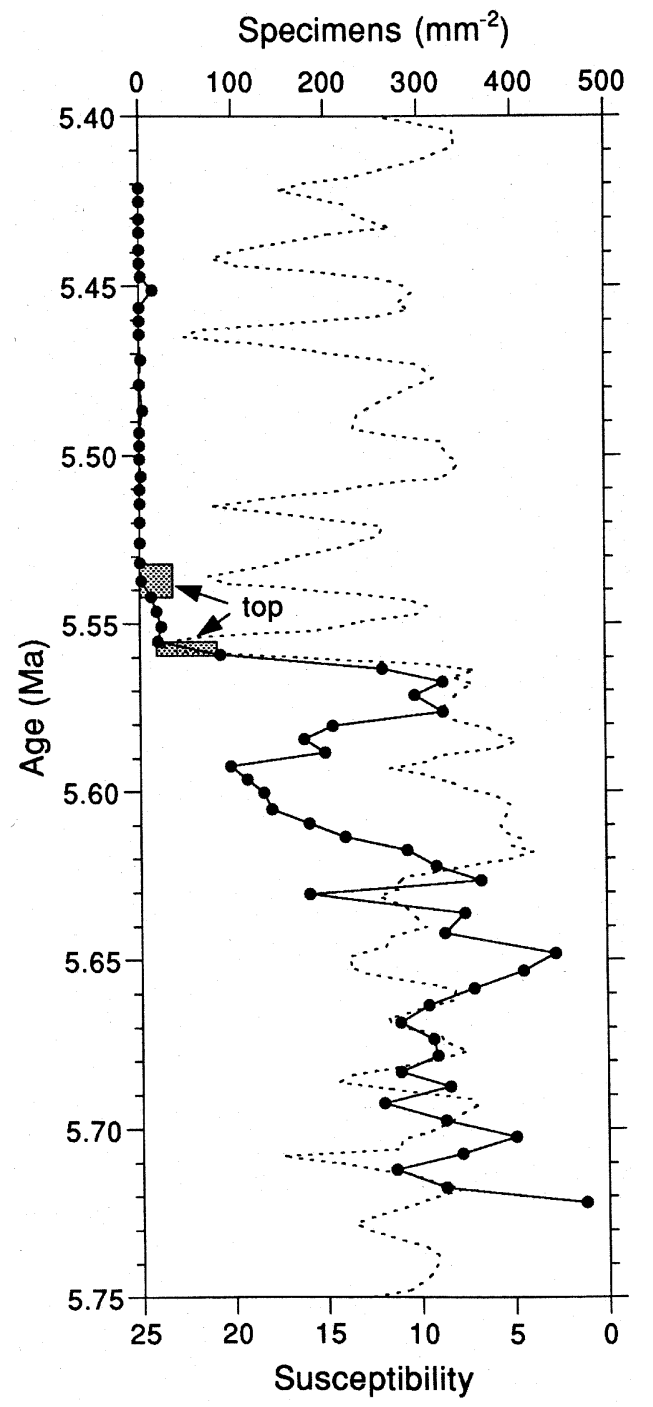

Figure 4. Abundances of Discoaster quinqueramus, Site 926. Two options for the placement of the extinction are indicated. See also explanation in Figure 2 .

\section{Range of Amaurolithus amplificus}

The genus Amaurolithus provides three biostratigraphically useful events for subdivision of the upper Miocene: the top and base of Amaurolithus amplificus and the base of Amaurolithus spp. (i.e., Amaurolithus primus). Counts representing the total range of $A$. amplificus are plotted in Figure 5. The results show generally low abundances and higher frequency variations. It was necessary to scan 50 view-fields and to use a larger view-field diameter $(0.28 \mathrm{~mm}$ at $790 \times$ magnification) to scan a total assemblage of about 10,000 specimens, for accurately determining the final abundance decrease of A. amplificus at Site 926.

Amaurolithus amplificus shows distinct, easily recognizable morphotypes throughout most of its range, except in its lowermost part. Gartner (1967) and Gartner and Bukry (1975) considered it "a remote possibility" that the family Ceratolithaceae originated from T. rugosus. The late Miocene nannofossil assemblages preserved at Site 926 show clearly that $A$. amplificus evolved from T. rugosus. A short interval at the very base of the range of A. amplificus, and immediately below the appearance of reasonably well-developed A. amplificus, is characterized by the presence of morphotypes showing a wide array

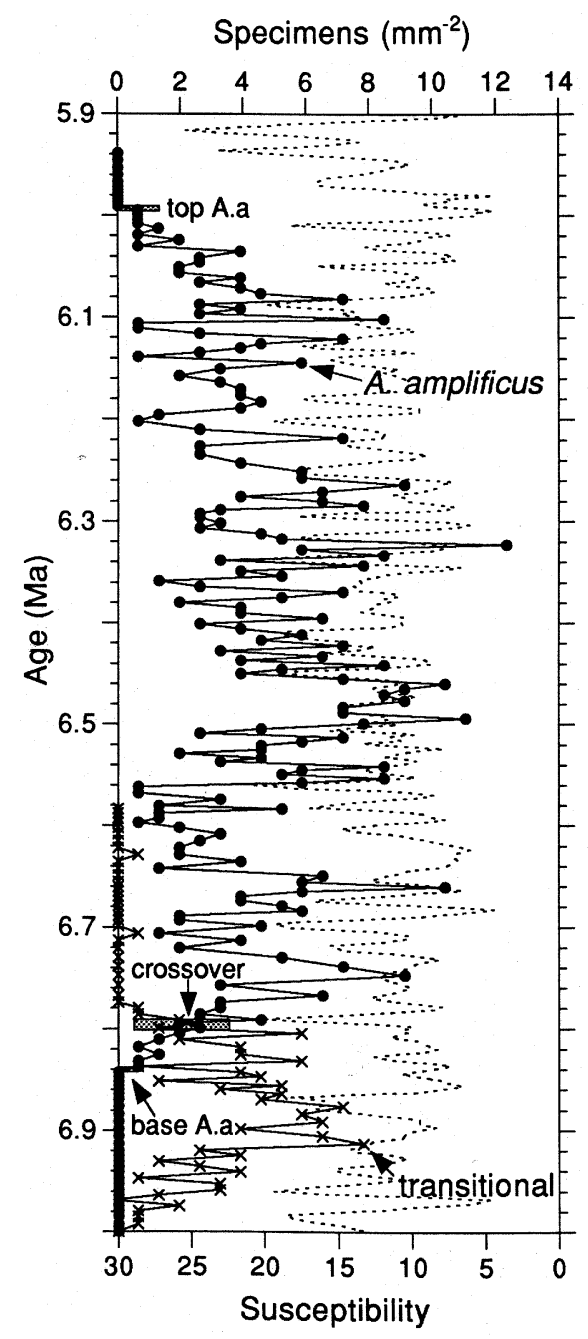

Figure 5. Abundances of Amaurolithus amplificus (A.a.) and transitional forms between A. amplificus and Triquetrorhabdulus rugosus, Site 926. See also explanation in Figure 2.

of transitional morphologies between A. amplificus and T. rugosus, making it difficult to determine the first occurrence of $A$. amplificus consistently. In fact, the appearance of A. amplificus is probably less sharp than indicated by the data in Figure 5. Malformed specimens of T. rugosus, similar to those occurring at the final part of the range of T. rugosus around the Miocene/Pliocene boundary, and forms that are transitional between $T$. rugosus and A. amplificus, are grouped in Figure 5. Therefore, we consider that the crossover in abundance between the transitional forms and A. amplificus can be more consistently determined by different nannofossil biostratigraphers than the first occurrence of A. amplificus. The most problematic interval of strongly intergrading morphologies is $0.8-\mathrm{m}$ long and occurred from the level of appearance of primitive A. amplificus at $6.840 \mathrm{Ma}$ to the abundance crossover at $6.798 \mathrm{Ma}$. The transition of T. rugosus into A. amplificus, however, occurred over $\sim 200$ k.y., between about 7.0 and $6.8 \mathrm{Ma}$, although the phase with strongly overlapping morphologies occurred during the final quarter of that time interval.

\section{Base of Amaurolithus spp.}

Abundances of Amaurolithus spp. are shown in Figure 6. This taxonomic category includes Amaurolithus primus, A. delicatus, and 
A

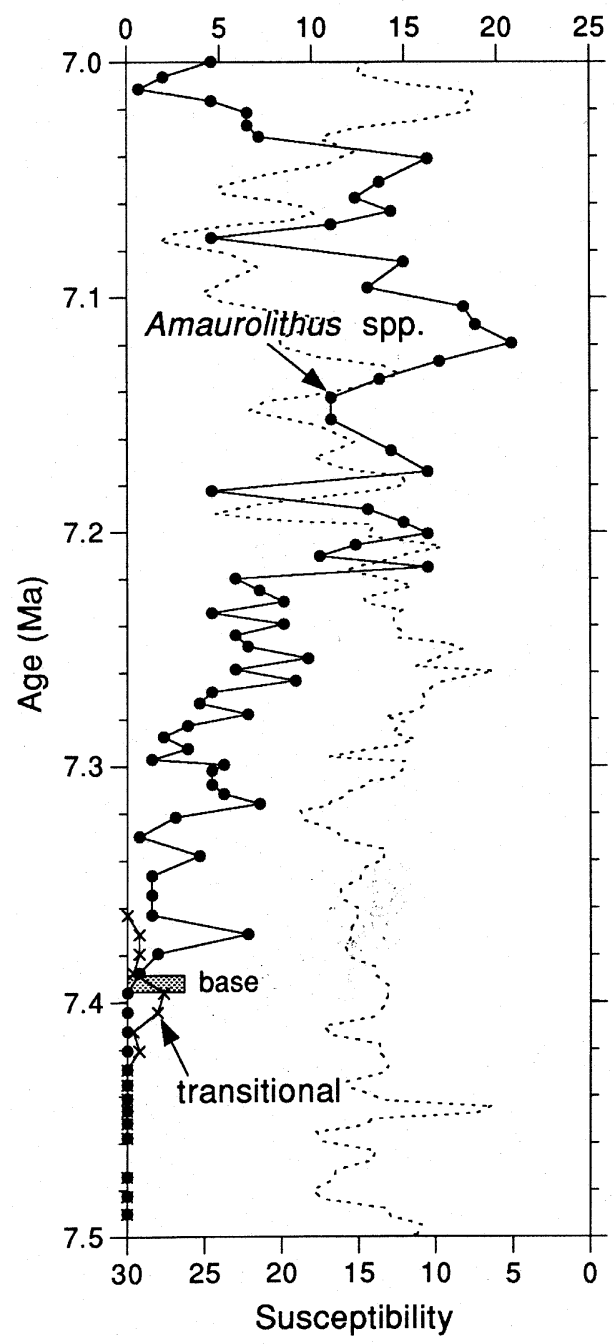

B

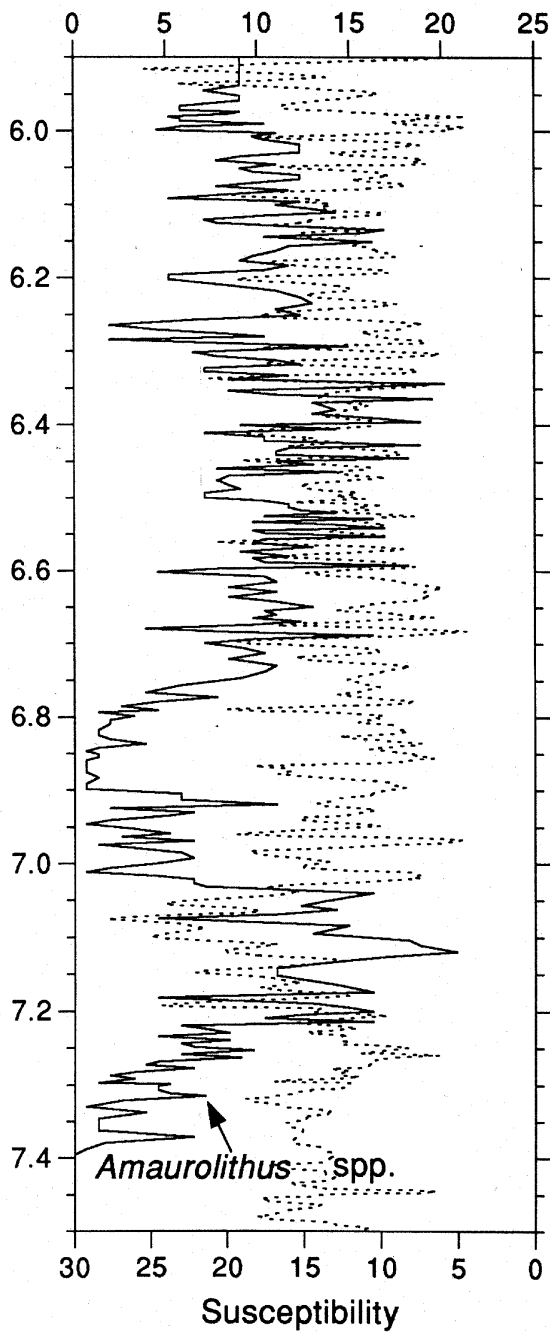

C

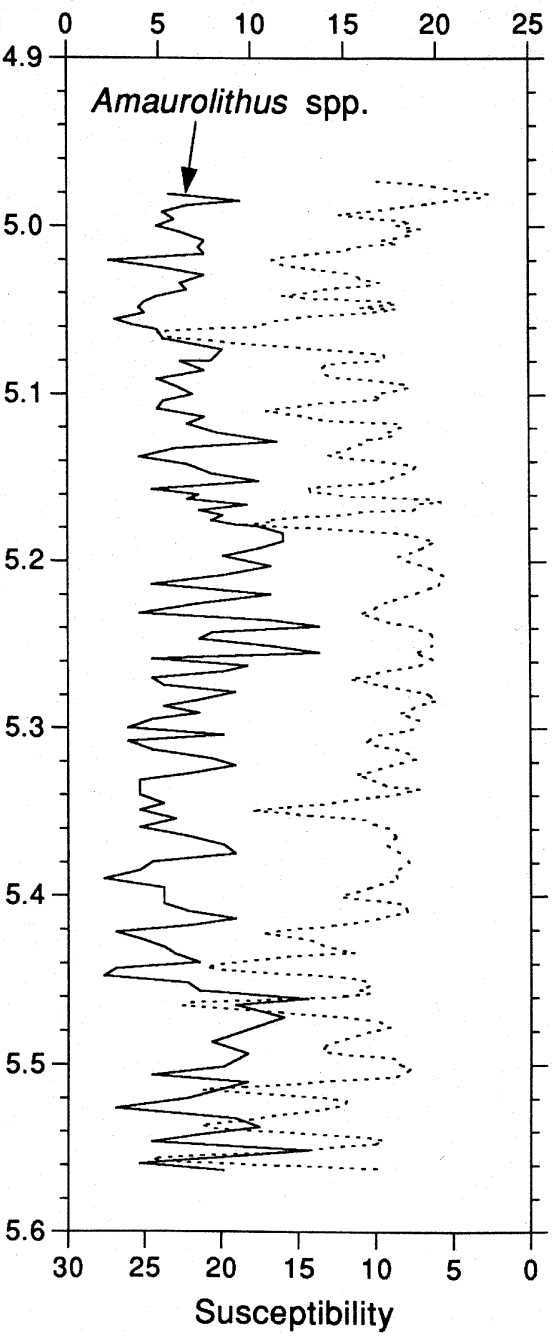

Figure 6. Abundances of Amaurolithus spp., Site 926. A. Data between 7.0 and 7.5 Ma and forms transitional between Triquetrorhabdulus rugosus and Amaurolithus spp. B. Data between 5.9 and 7.5 Ma. C. Data between 4.9 and 5.6 Ma. See also explanation in Figure 2.

A. tricorniculatus, but not $A$. amplificus. The counts represent the entire late Miocene range of this group, except for a data gap between 5.563 and 5.939 Ma. Amaurolithus spp. are consistently present in low abundances and show higher frequency variations. The first occurrence of this genus (i.e., of A. primus) occurred in a short interval showing morphotypes that are transitional between $T$. rugosus and Amaurolithus spp. That is, A. primus evolved from T. rugosus, indicating that late Miocene members of the family Ceratolithaceae repeatedly radiated from $T$. rugosus. Malformed, transitional morphotypes between $T$. rugosus occurred in short intervals during each speciation event, but these morphotypes are rare between the speciation events. An Amaurolithus spp. morphotype that is not readily assigned to any of the conventional late Miocene species was observed in low abundances, primarily in the basal range of Amaurolithus spp. The typical U-shape of Amaurolithus spp. is blurred by a veil of calcite filling much of the space between the two horns. This morphotype has been discussed by Rio et al. (1990, pl. 7) from Leg 115 sediments and by Raffi et al. (1995) from Leg 138 sediments.

\section{Base of Discoaster berggrenii}

Discoaster berggrenii evolved from the Discoaster bellus group. Transitional morphotypes that have the characteristic outline of $D$. berggrenii with a distinct central area, but a poorly developed (or absent) central knob, were observed. The gradual development toward the possession of a distinct central area knob by typical $D$. berggrenii (Raffi and Flores, 1995) made it difficult to determine the first occurrence event. Typical $D$. berggrenii showed generally low abundances in its lower range, and we did not observe a distinct abundance crossover from the $D$. bellus group. In Leg 138 sediments, Raffi et al. (1995) observed a range from sharp to less distinct initial abundance patterns of $D$. berggrenii. Furthermore, it may be difficult to determine the evolutionary transition from the $D$. bellus group to $D$. berggrenii in samples showing secondary overgrowth of calcite. The initial abundance pattern of $D$. berggrenii from Site 926 is shown in Figure 7 .

\section{Paracme Interval of Reticulofenestra pseudoumbilicus}

A late Miocene interval lacking Reticulofenestra pseudoumbilicus $(>7 \mu \mathrm{m})$ was observed by Rio et al. (1990) from the equatorial Indian Ocean, and subsequently by Takayama (1993) and Raffi and Flores (1995) from the western and eastern extremes of the equatorial Pacific Ocean, respectively. Gartner (1992) also observed a drastic decrease in reticulofenestrid size "near the base of Chron 4" from the mid-latitude North Atlantic. Rio et al. (1990) referred to this interval 


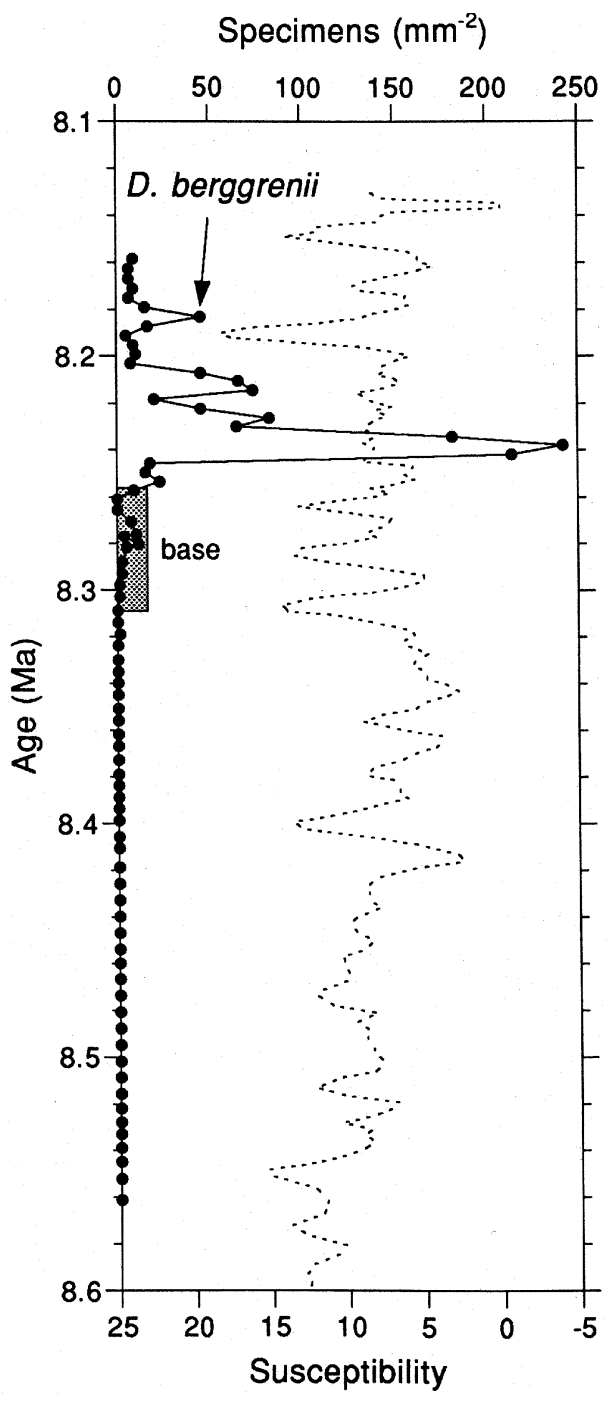

Figure 7. Abundances of Discoaster berggrenii, Site 926. See also explanation in Figure 2.

as the R. pseudoumbilicus paracme. The base and top of this paracme interval provide two biostratigraphically useful events in the western equatorial Atlantic Ocean (Fig. 8). We used 30-cm sample-spacing intervals when scanning samples well within this paracme interval. The size concept is critical because using a 5- or 6- $\mu$ m concept would yield $R$. pseudoumbilicus morphotypes within the paracme interval at Site 926.

\section{Events Around the Middle/Late Miocene Boundary}

\section{Events Based on Discoaster hamatus, Discoaster neohamatus,} and Discoaster brouweri

There is no unequivocal agreement regarding the placement of the middle/late Miocene boundary, except perhaps that it should be placed within the range of Discoaster hamatus, as discussed by Rio et al. (1990). Events provided by three Discoaster species are plotted in Figure 9: the total range of the five-rayed D. hamatus, the lowermost part of the range of the six-rayed Discoaster brouweri, and the lower range of the six-rayed Discoaster neohamatus. The total range of $D$. hamatus encompassed about $840 \mathrm{k}$.y. The uppermost part is characterized by low abundance and sporadic occurrences, whereas the base is better constrained in terms of abundance behavior. Discoaster neohamatus appeared only about $26 \mathrm{k} . \mathrm{y}$. after the first occur- rence of $D$. hamatus, but it showed consistently lower abundances than $D$. hamatus, or was absent until the very top of the range of $D$. hamatus, where a distinct abundance crossover occurred. This crossover clearly represents a more easily recognized bioevent than the top of D. hamatus at Site 926 . Minor occurrences of D. hamatus before 10.476 Ma are considered to represent a downhole contamination problem that is restricted to the composite depth section in Core 154926A-25H. Several samples showed contaminated species between Samples 154-926A-25H-2, $115 \mathrm{~cm}$, and 25H-5, $35 \mathrm{~cm}$ (i.e., between 10.569 and $10.881 \mathrm{Ma}$ ). We reanalyzed this interval from the corresponding interval in Hole 926C and did not observe contamination there. The data in Figure 9, however, represent the contaminated core, which serves the purpose of again demonstrating the advantage of the "quantitative data-short sample distance" approach, because traditional biostratigraphy would have mistakenly placed the lowest occurrence in the contaminated samples. Discoaster brouweri has a distinct first occurrence about $211 \mathrm{k}$.y. before the base of $D$. hamatus. The distinct rise in abundance of the two six-rayed species $D$. brouweri and $D$. neohamatus occurred concomitantly, which perhaps may explain the simultaneous demise of the five-rayed $D$. hamatus. Finally, the uppermost range of $D$. neohamatus was difficult to determine precisely, chiefly because it is transitional with the $D$. brouweri morphotype.

\section{Ranges of Catinaster coalitus and Catinaster calyculus}

The genus Catinaster existed for about 1.15 m.y. around the middle/late Miocene boundary and consisted of at least two distinct species: Catinaster coalitus and Catinaster calyculus. The total range of both species are shown in Figure 10. The ancestor species $C$. coalitus has a distinct first occurrence; the single sample abundance spike at 10.881 Ma represents contamination in Core 154-926A-25H. The lower part of the range is characterized by high, strongly varying abundances, which are followed by reduced abundances in the upper part of the range. The abundance change is probably related to the opposite change that occurred in the descendant species $C$. calyculus, which shows low abundances in its lower range and higher abundances in the upper part. The extinction of $C$. calyculus was represented by a distinct final abundance decline in contrast to $C$. coalitus.

The small discoaster species Discoaster micros was described from the eastern equatorial Atlantic Ocean by Theodoridis (1984). The nannofossil assemblages preserved at Site 926 clearly show that C. coalitus evolved from D. micros. Forms transitional between the two species occurred abundantly for about $30 \mathrm{~cm}$, or 24 k.y., before the appearance of true $C$. coalitus (Fig. 10). In stratigraphic sections where the entire evolutionary lineage is preserved, as at Site 926, the abundance crossover between $D$. micros and transitional forms on the one hand, and true $C$. coalitus on the other, probably represents the event that can be determined most consistently.

Finally, the time-dependent proportional change between $C$. coalitus and $C$. calyculus is shown in Figure 11. A crossover between the two species occurred at $10.357 \mathrm{Ma}$, which may represent an evolutionary event and thus a potentially useful biostratigraphic marker event. This crossover is followed by a few reversals in abundance, but the first time when $C$. calyculus showed dominance among catinasters may prove to represent a valuable new bioevent.

\section{Top of Coccolithus miopelagicus}

The extinction of Coccolithus miopelagicus occurred about $1.8 \mathrm{~m}$, or 236 k.y., below the base of C. coalitus at Site 926 (Fig. 12). Bukry (1971, 1973) suggested that $C$. miopelagicus disappeared within the range $C$. coalitus, based on observations from low-latitude sites. Observations supporting those of Bukry $(1971,1973)$ were made by Raffi et al. (1995) from Sites 844 and 845 in the eastern equatorial Pacific Ocean, and Site 714 in the equatorial Indian Ocean. In contrast, Kroenke, Berger, Janecek, et al. (1991, p. 311) observed that the "LO 
A

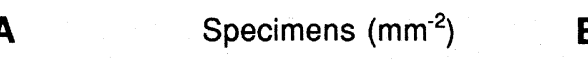

B Specimens $\left(\mathrm{mm}^{-2}\right)$
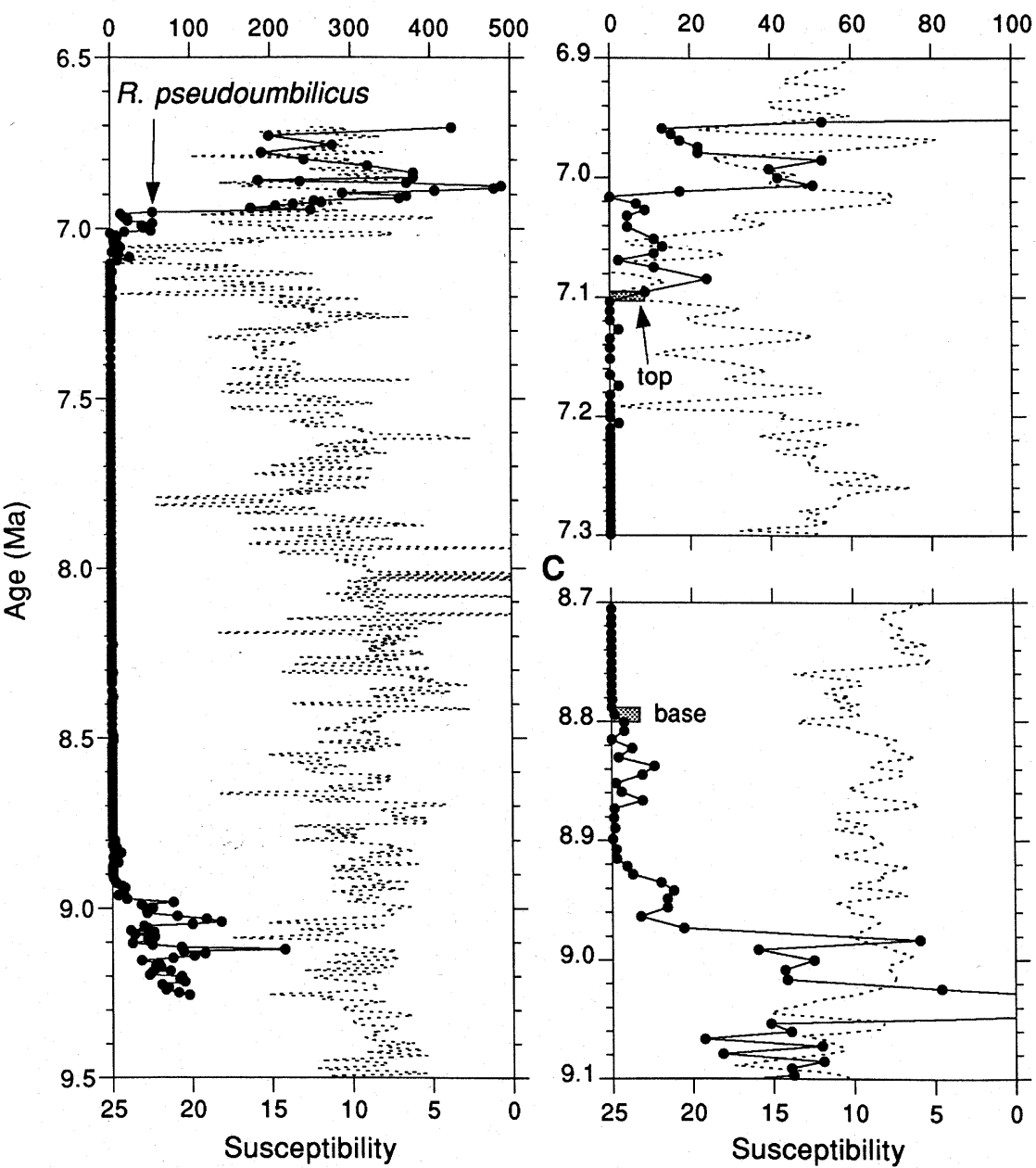

Figure 8. A. Abundances of Reticulofenestra pseudoumbilicus ( $>7 \mu \mathrm{m})$, Site 926. B. Increased scale resolution of the top of the paracme interval. $\mathbf{C}$. Increased scale resolution of the base of the paracme interval. See also explanation in Figure 2.

of C. miopelagicus appears to fall immediately below Zone NN8," that is, immediately below the appearance of $C$. coalitus, in the western equatorial Pacific Ocean. The fact that the evolutionary transition from ancestral $D$. micros to descendant $C$. coalitus is preserved at Site 926 is interpreted to imply that $C$. miopelagicus, rather than $C$. coalitus, showed diachrony.

\section{Middle Miocene Events \\ Range of Discoaster kugleri}

The stratigraphic distribution of Discoaster kugleri is considered problematic either because it is difficult to recognize in less well-preserved assemblages or because of its short range with "common and continuous distribution" (Fornaciari et al., 1990; Gartner, 1992; Raffi and Flores, 1995). During Leg 154, therefore, we applied "Base common" (Bc) and "Top common" (Tc) concepts, which represent an easily observed rise and decline in abundance, respectively. The arbitrary definition used for these events was drawn at an average abundance of about one specimen per every other field of view, that is, scanning 30 fields of view at a particle density of 100-150 nannofossils per view-field should yield a minimum of $15 \mathrm{D}$. kugleri specimens. Quantitative counts showed that $D$. kugleri has a short distinct range in Site 926 sediments (Fig. 13), with both the top and base occurring approximately $34 \mathrm{k} . \mathrm{y} .(<1 \mathrm{~m})$ after, and before, the Tc and Bc events, respectively. Gartner's (1992) observation of "very rare" abundances in a 3-m short interval immediately below Chron C5r.2n at Site 608 in the mid-latitude North Atlantic Ocean, about $11.5 \mathrm{Ma}$ according to the Leg 154 shipboard time scale, probably is synchronous with its abundant occurrences in a 4-m short interval beginning at $11.797 \mathrm{Ma}$ and ending at $11.554 \mathrm{Ma}$ at Site 926 . Interestingly, Gartner's "very rare" concept presumably represents a relative abundance ranging from $0.01 \%$ to $0.04 \%$ of the total assemblage. Converting our counts of $D$. kugleri into relative abundances, one specimen would represent $0.03 \%-0.04 \%$ of the total assemblage. The combination of short total duration (just over 300 k.y. at Site 926) and generally low relative abundances may perhaps explain the lack of observed occurrences of D. kugleri. On the other hand, in well-preserved Discoaster assemblages, this species is an ideal biostratigraphic index fossil with its wide geographic distribution and short stratigraphic range.

\section{Top of Sphenolithus heteromorphus}

A rare suite of low-latitude Neogene sediments with continuous magnetostratigraphy was recovered during Leg 138 . The oldest polarity zone was recovered from Site 845 , where the magnetostratigraphic section ended in Chron C5ABn, one core above the extinction of Sphenolithus heteromorphus (Mayer, Pisias, Janecek, et al., 1992). The extinction of $S$. heteromorphus occurred in Chron C5ABr in the equatorial Indian Ocean (Site 710; Backman et al., 1990), and in the mid-latitude North Atlantic Ocean (Site 608; Olafsson, 1991) (i.e., between 13.466 and $13.666 \mathrm{Ma}$ according to the Leg 154 ship- 
Table 1. Summary of positions and age estimates of Site 926 nannofossil bioevents.

\begin{tabular}{|c|c|c|c|c|}
\hline Event & $\begin{array}{c}\text { Nannofossil } \\
\text { marker }\end{array}$ & $\begin{array}{l}\text { Core, section, } \\
\text { interval }(\mathrm{cm})\end{array}$ & $\begin{array}{l}\text { Depth } \\
\text { (mcd) }\end{array}$ & Age (Ma) \\
\hline \multirow[t]{2}{*}{$\mathrm{T}$} & C. acutus & 926B-15H-5, 145 & 154.82 & $5.046 \pm 0.002$ \\
\hline & & & 154.92 & \\
\hline $\mathrm{X}$ & C. acutus & $926 \mathrm{~B}-15 \mathrm{H}-6,55$ & 155.42 & $5.070 \pm 0.003$ \\
\hline \multirow{2}{*}{ B } & $\begin{array}{l}\text { C. rugosus } \\
\text { C. rugosus }\end{array}$ & $\begin{array}{l}926 \mathrm{~B}-15 \mathrm{H}-6,65 \\
926 \mathrm{C}-15 \mathrm{H}-4,28\end{array}$ & $\begin{array}{l}155.52 \\
155.73\end{array}$ & $5.089 \pm 0.003$ \\
\hline & & $926 \mathrm{C}-15 \mathrm{H}-4,38$ & 155.83 & $5.003-0.003$ \\
\hline \multirow[t]{2}{*}{$\mathrm{T}$} & T. rugosus & $926 \mathrm{~A}-16 \mathrm{H}-3,55$ & 158.51 & $5.231 \pm 0.023$ \\
\hline & & $926 \mathrm{~A}-16 \mathrm{H}-4,5$ & 159.51 & \\
\hline \multirow[t]{2}{*}{$\mathrm{T}$} & C. atlanticus & $926 \mathrm{~A}-16 \mathrm{H}-3,95$ & 158.91 & $5.233 \pm 0.002$ \\
\hline & & $926 \mathrm{~A}-16 \mathrm{H}-3,115$ & 159.01 & \\
\hline \multirow[t]{2}{*}{$\mathrm{T}$} & Ceratolithus sp. 1 & $926 \mathrm{~A}-16 \mathrm{H}-4,25$ & 159.71 & $5.264 \pm 0.002$ \\
\hline & & $926 \mathrm{~A}-16 \mathrm{H}-4,35$ & 159.81 & \\
\hline \multirow[t]{2}{*}{ B } & Ceratolithus sp. 1 & $926 \mathrm{~A}-15 \mathrm{H}-5,45$ & 161.41 & $5.338 \pm 0.002$ \\
\hline & & $926 \mathrm{~A}-16 \mathrm{H}-5,55$ & 161.51 & \\
\hline \multirow[t]{2}{*}{ B } & C. acutus & $926 \mathrm{~A}-16 \mathrm{H}-5,115$ & 162.11 & $5.372 \pm 0.003$ \\
\hline & & $926 \mathrm{~A}-16 \mathrm{H}-5,125$ & 162.21 & \\
\hline \multirow[t]{2}{*}{ B } & C. atlanticus & 926A-16H-6, 15 & 162.61 & $5.398 \pm 0.003$ \\
\hline & & 926A-16H-6, 25 & 162.71 & \\
\hline \multirow[t]{2}{*}{$\mathrm{T}$} & D. quinqueramus & $926 \mathrm{C}-16 \mathrm{H}-3,73$ & 165.39 & $5.537 \pm 0.005$ \\
\hline & & $926 \mathrm{C}-16 \mathrm{H}-3,93$ & 165.59 & \\
\hline \multirow[t]{2}{*}{$\mathrm{T}$} & A. amplificus & $926 \mathrm{C}-17 \mathrm{H}-3,38$ & 175.61 & $5.993 \pm 0.002$ \\
\hline & & $926 \mathrm{C}-17 \mathrm{H}-3,48$ & 175.71 & \\
\hline \multirow[t]{2}{*}{$\mathrm{X}$} & T. rugosus & $926 \mathrm{C}-18 \mathrm{H}-6,115$ & 190.14 & $6.798 \pm 0.006$ \\
\hline & A. amplificus & $926 \mathrm{~B}-19 \mathrm{H}-1,55$ & 190.39 & \\
\hline \multirow[t]{2}{*}{ B } & A. amplificus & 926B-19H-1, 105 & 190.89 & $6.840 \pm 0.003$ \\
\hline & & 926B-19H-1, 115 & 190.99 & \\
\hline T-pa & R. pseudoumbilicus & 926B-19H-4, 75 & 195.09 & $7.100 \pm 0.004$ \\
\hline & & $926 \mathrm{~B}-19 \mathrm{H}-4,85$ & 195.19 & \\
\hline B & Amaurolithus spp. & $926 \mathrm{~A}-20 \mathrm{H}-2,126$ & 199.74 & $7.392 \pm 0.004$ \\
\hline & & $926 \mathrm{~A}-20 \mathrm{H}-2,136$ & 199.84 & \\
\hline B & D. berggrenii & 926B-21H-5, 135 & 217.04 & $8.281 \pm 0.028$ \\
\hline & & $926 \mathrm{C}-22 \mathrm{H}-1,108$ & 218.16 & \\
\hline B-pa & R. pseudoumbilicus & $926 \mathrm{~B}-22 \mathrm{H}-4,145$ & 225.31 & $8.788 \pm 0.013$ \\
\hline & & 926B-22H-5, 35 & 225.71 & \\
\hline $\mathrm{T}$ & D. hamatus & $926 \mathrm{~B}-23 \mathrm{H}-5,35$ & 237.42 & $9.635 \pm 0.028$ \\
\hline & & 926B-23H-5, 105 & 238.12 & \\
\hline $\mathrm{T}$ & C. calyculus & $926 \mathrm{~B}-23 \mathrm{H}-5,75$ & 237.82 & $9.641 \pm 0.004$ \\
\hline & & 926B-23H-5, 85 & 237.92 & \\
\hline $\mathrm{T}$ & C. coalitus & 926B-23H-6, 5 & 238.62 & $9.694 \pm 0.003$ \\
\hline & & 926B-23H-6, 15 & 238.72 & \\
\hline$X$ & D. hamatus & 926A-24H-2, 95 & 240.05 & $9.771 \pm 0.003$ \\
\hline & D. neohamatus & $926 \mathrm{~A}-24 \mathrm{H}-2,105$ & 240.15 & \\
\hline $\mathrm{X}$ & C. calyculus & 926B-24H-5, 25 & 247.77 & $10.357 \pm 0.004$ \\
\hline & C. coalitus & 926B-24H-5, 35 & 247.87 & \\
\hline B & D. neohamatus & 926B-24H-6, 15 & 249.17 & $10.450 \pm 0.003$ \\
\hline & & 926B-24H-6, 25 & 249.27 & \\
\hline B & D. hamatus & 926B-24H-6, 45 & 249.47 & $10.476 \pm 0.010$ \\
\hline & & 926B-24H-6, 75 & 249.77 & \\
\hline B & D. brouweri & $926 \mathrm{~A}-25 \mathrm{H}-3,95$ & 252.30 & $10.687 \pm 0.007$ \\
\hline & & $926 \mathrm{~A}-25 \mathrm{H}-3,115$ & 252.50 & \\
\hline B & C. calyculus & $926 \mathrm{~A}-25 \mathrm{H}-3,115$ & 252.50 & $10.705 \pm 0.011$ \\
\hline & & $926 \mathrm{~A}-25 \mathrm{H}-3,145$ & 252.80 & \\
\hline $\mathrm{X}$ & D. micros + transition & $926 \mathrm{~A}-25 \mathrm{H}-4,55$ & 253.40 & $10.777 \pm 0.004$ \\
\hline & C. coalitus & $926 \mathrm{~A}-25 \mathrm{H}-4,65$ & 253.50 & \\
\hline B & C. coalitus & $926 \mathrm{~A}-25 \mathrm{H}-4,75$ & 253.60 & $10.794 \pm 0.004$ \\
\hline & & $926 \mathrm{~A}-25 \mathrm{H}-4,85$ & 253.70 & \\
\hline $\mathrm{T}$ & C. miopelagicus & $926 \mathrm{~A}-25 \mathrm{H}-5,95$ & 255.30 & $10.941 \pm 0.010$ \\
\hline & & $926 \mathrm{~A}-25 \mathrm{H}-5,125$ & 255.60 & \\
\hline $\mathrm{T}$ & D. kugleri & $926 \mathrm{~A}-26 \mathrm{H}-2,55$ & 262.41 & $11.520 \pm 0.012$ \\
\hline & & $926 \mathrm{~A}-26 \mathrm{H}-2,85$ & 262.71 & \\
\hline $\mathrm{Tc}$ & D. kugleri & $926 \mathrm{~A}-26 \mathrm{H}-2,105$ & 262.91 & $11.554 \pm 0.006$ \\
\hline & & $926 \mathrm{~A}-26 \mathrm{H}-2,115$ & 263.01 & \\
\hline $\mathrm{Bc}$ & D. kugleri & $926 \mathrm{~A}-26 \mathrm{H}-4,125$ & 266.11 & $11.797 \pm 0.003$ \\
\hline & & $926 \mathrm{~A}-26 \mathrm{H}-4,135$ & 266.21 & \\
\hline B & D. kugleri & 926B-26H-3, 35 & 266.62 & $11.831 \pm 0.003$ \\
\hline & & $926 \mathrm{~B}-26 \mathrm{H}-3,45$ & 266.72 & \\
\hline $\mathrm{T}$ & S. heteromorphus & 926B-29X-4, 55 & 293.86 & $13.523 \pm 0.011$ \\
\hline & & 926B-29X-4, 95 & 294.26 & \\
\hline
\end{tabular}

Notes: Depth given in meters composite depth $(\mathrm{mcd}) . \mathrm{T}=$ top, $\mathrm{B}=$ base, $\mathrm{X}=$ abundance cross-over; T-pa $=$ top paracme; B-pa $=$ base paracme; $\mathrm{Tc}=$ top common $(\sim 1$ specimen in every second field of view); $\mathrm{Bc}=$ base common; "D. micros + transition" represents both D. micros and transitional forms between D. micros and C. coalitus.

board time scale). With an estimated age of $13.523 \mathrm{Ma}$, the top of $S$. heteromorphus represents the oldest investigated event in Site 926 in the interval with orbitally tuned time control (Shackleton and Crowhurst, this volume; Fig. 14). Strong fluctuations in preservation characterized several samples toward the very end of the range of $S$. heteromorphus, which may have contributed toward obscuring the fi- nal abundance decline. Yet, despite the larger depth uncertainty, the $S$. heteromorphus event could be determined to \pm 11 k.y.

\section{SUMMARY OF SITE 926 AGE CALIBRATIONS}

Thirty-four middle and late Miocene nannofossil events have been determined with $10-\mathrm{cm}$ sampling resolution from Site 926 in the western equatorial Atlantic Ocean. These bioevents have been assigned age estimates through calibration to the orbitally tuned time scale of Shackleton and Crowhurst (this volume). This time scale, which extends back to $14 \mathrm{Ma}$, was constructed on the basis of cyclic lithological variations documented by color reflectance and magnetic susceptibility measurements. Before their effort, orbitally tuned time scales extended to about $5 \mathrm{Ma}$ from both middle and low latitudes (Hilgen, 1991; Shackleton et al., 1995b). Such time scales have been extended back to about $9.7 \mathrm{Ma}$ in the middle latitudes (Hilgen et al., 1995). These efforts clearly represent major advances in mid- and low-latitude cyclochronologic time control, both in terms of resolution and accuracy. The present investigation, which is focused on material from the Ceara Rise, encompasses the earliest Pliocene and Miocene time intervals from 5.046 to $13.523 \mathrm{Ma}$, thus taking advantage of the entire low-latitude advance in astrochronological control. Age calibrations of nannofossils from Site 926 are summarized in Table 1 and Figure 15, showing that events are calibrated with age uncertainties ranging from \pm 2 to $\pm 28 \mathrm{k}$.y. This study of nannofossil biostratigraphy resulted in an average resolution of $250 \mathrm{k} . \mathrm{y}$. throughout the 8.477-m.y. time interval investigated, at an average event resolution of \pm 7 k.y. (Table 1).

Site 926 sediments are well suited to serve as a reference section for the calcareous plankton biostratigraphy from the low-latitude Atlantic Ocean in the 0- to 14-Ma interval because of completeness in deposition and recovery, superbly resolved independent chronologic control, and the fact that it represents a location where nannofossil speciation occurred. Further, carbonate preservation is generally good. Enhanced dissolution occurring in a strongly cyclic fashion was observed only in a 4-m-thick interval from about 265 to $269 \mathrm{mcd}$ (approximately 11.7-12.0 Ma), where a single sample at $267.92 \mathrm{mcd}$ (11.910 Ma; Sample 154-926B-26H-4, 14-16 cm) was barren of nannofossils (see magnetic susceptibility record in Curry, Shackleton, Richter, et al., 1995, p. 171). This single barren sample indicates a rapid excursion in the position of the calcite compensation depth toward the end of the middle Miocene.

The majority of the 34 nannofossil events investigated have been determined to within $10 \mathrm{~cm}$ and are considered easily recognizable in terms of abundance behavior. In contrast, the following events are more difficult to constrain precisely: tops of T. rugosus, D. hamatus, and $C$. coalitus and bases of $A$. amplificus, D. berggrenii, D. neohamatus, and C. calyculus.

Reworking is not evident in any part of the investigated interval (Curry, Shackleton, Richter, et al., 1995), suggesting that the low abundances just below the tops of T. rugosus, D. hamatus, and C. coalitus, and just above the base of $C$. calyculus, represent indigenous occurrences. The lack of other similarly resolved, quantitative studies of these four bioevents, however, largely prevents conclusions about whether or not the low abundances immediately before or after the bioevents represent a local, western equatorial Atlantic effect. Counts of relative abundance changes of $C$. coalitus and $C$. calyculus may represent an effective way to determine the base of $C$. calyculus and the top of $C$. coalitus. The problems with the bases of $A$. amplificus and $D$. berggrenii clearly result from the presence of evolutionary transitional forms between ancestral and descendant morphotypes.

Several sediment sections of late Miocene age were recovered during Leg 138. Site 849 is located on the equator in the eastern Pacific Ocean, presently lying in the South Equatorial Current. Amaurolithus amplificus was reported to have an unusually short range at 


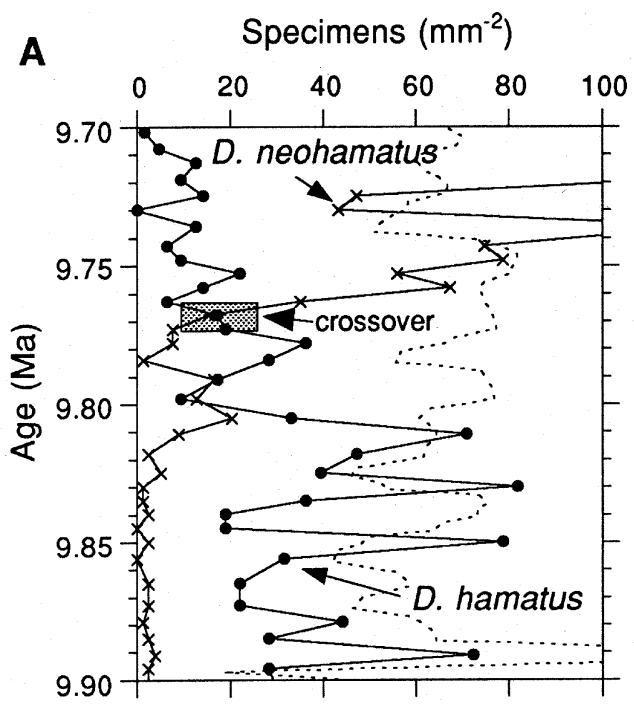

C

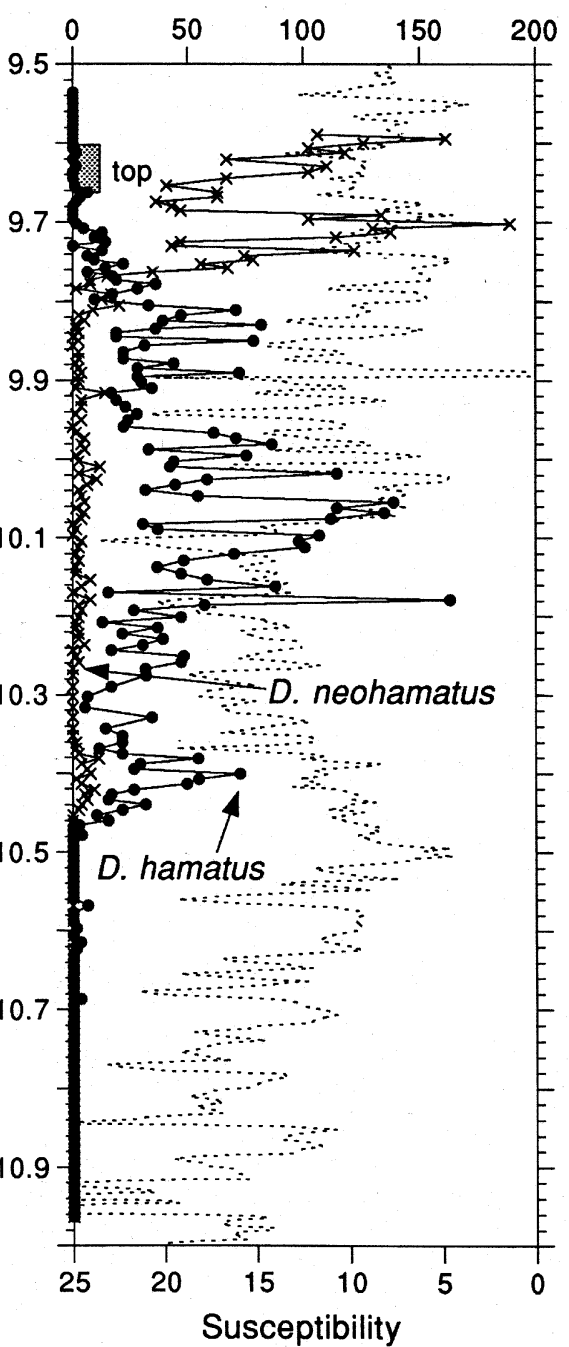

Specimens $\left(\mathrm{mm}^{-2}\right)$

sceptibility
D Specimens $\left(\mathrm{mm}^{-2}\right)$

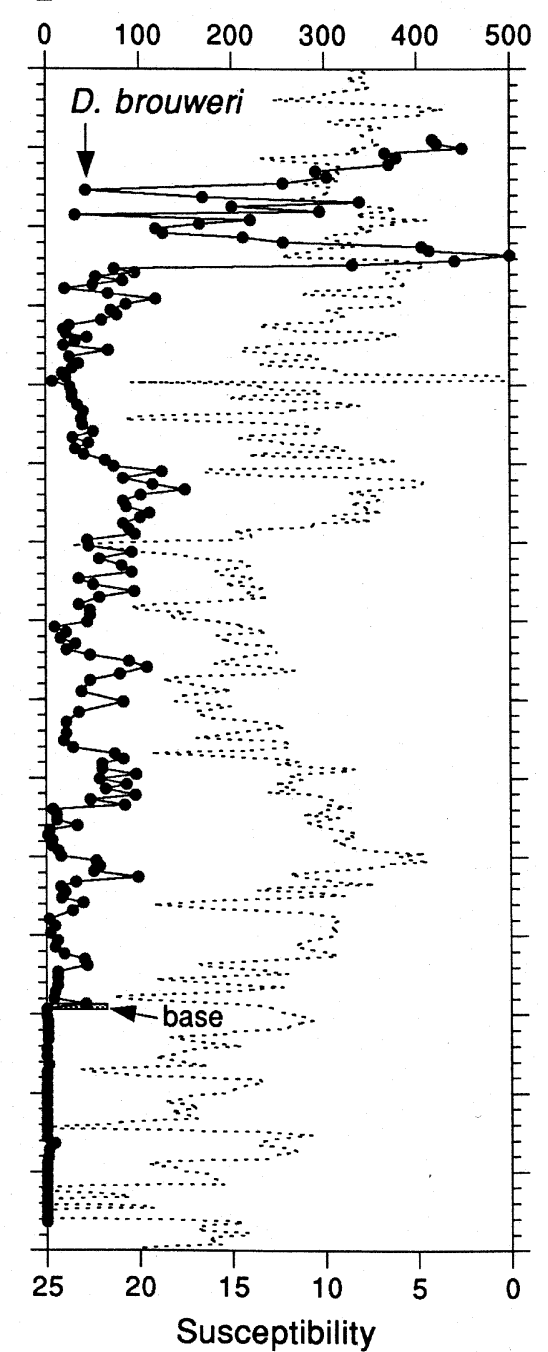

B

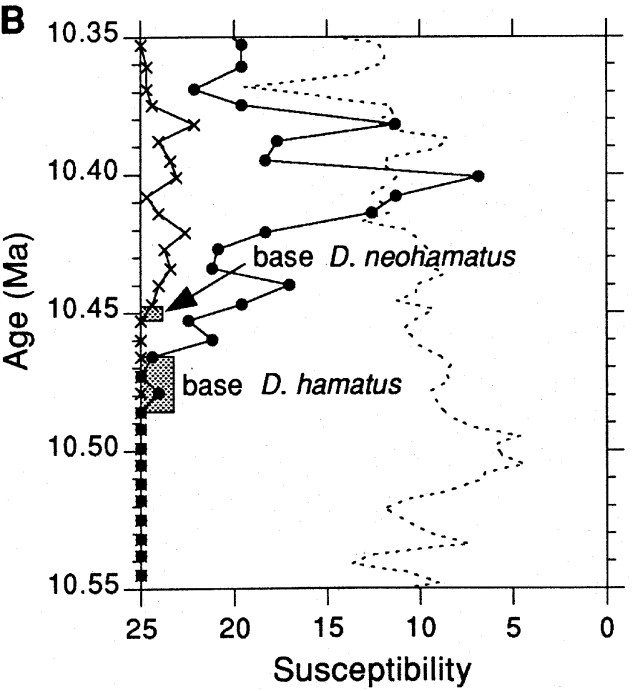

Figure 9. Abundances of the lowermost range of Discoaster hamatus and Discoaster neohamatus (C), and Discoaster brouweri (D), Site 926. A-B. Increased scale resolution of the abundance record from Figure 9C. See also explanation in Figure 2.

that site, despite continuous recovery of the critical stratigraphic interval (Mayer, Pisias, Janecek, et al., 1992). Considering that no restriction of equatorial surface water flow across the central American seaway occurred during late Miocene times (e.g., Keigwin, 1978), and given the comparatively short distance between Sites 849 and 926, we decided to reanalyze Site 849 (Fig. 16). Amaurolithus amplificus occurred in low abundance in a few samples only, suggesting that ecological factor(s) largely prevented production of A. amplificus at Site 849. The low abundance was not caused by dissolution, and we therefore speculate that intense upwelling conditions, resulting in sedimentation rates of about $50 \mathrm{~m} / \mathrm{m}$.y., provided the ecological factor(s) that excluded $A$. amplificus from the nannofossil assemblages.

Site 853 was drilled due north of Site 849 , at $7^{\circ} \mathrm{N}$ within the present Counter Current. Site 853 contained a longer range of $A$. amplificus, and we investigated its lowermost part in detail for comparison to Site 926. Late Miocene sedimentation rates at Site 853 were on the order of $15 \mathrm{~m} / \mathrm{m} . \mathrm{y}$. (Mayer, Pisias, Janecek, et al., 1992), or about one-third of the corresponding rate at Site 849. A short interval containing $T$. rugosus, malformed T. rugosus, transitional forms between $T$. rugosus and A. amplificus, and subsequently true A. amplificus also was observed at Site 853 (as discussed by Raffi and Flores,
1995), implying that the identical evolutionary sequence occurred in both the western equatorial Atlantic and the eastern equatorial Pacific oceans. Relative abundances of $T$. rugosus and the transitional morphotypes are shown in Figure 17.

The late Miocene time scale used on Leg 154 was derived from the biomagnetochronology obtained from Leg 138. A comparison between the Leg 138 time scale and the present Site 926 time scale clearly shows that the center of the peak in abundance of transitional morphotypes, relative to T. rugosus, occurred 120-130 k.y. after the corresponding peak center at Site 926. The age model in the critical interval at Site 853 was extrapolated from Chron C3An.n2. When applying the new age estimates of the relevant reversal boundaries (Hilgen et al., 1995), the peak center of transitional morphotypes coincide at Sites 853 and 926, lending strong support to Hilgen's astronomically tuned late Miocene time scale.

Comparison of the new age estimates (Table 1) with those used during the Leg 154 shipboard work (i.e., with the Leg 138 Miocene time scale) suggests that all new age estimates are older, or near equal to, the estimates used during the shipboard work, except in the case of the base of $D$. berggrenii, which shows a new age estimate some 119 k.y. younger. During the shipboard work, the base of $D$. berggrenii was used as a control point for calculating sedimentation rates, 
A
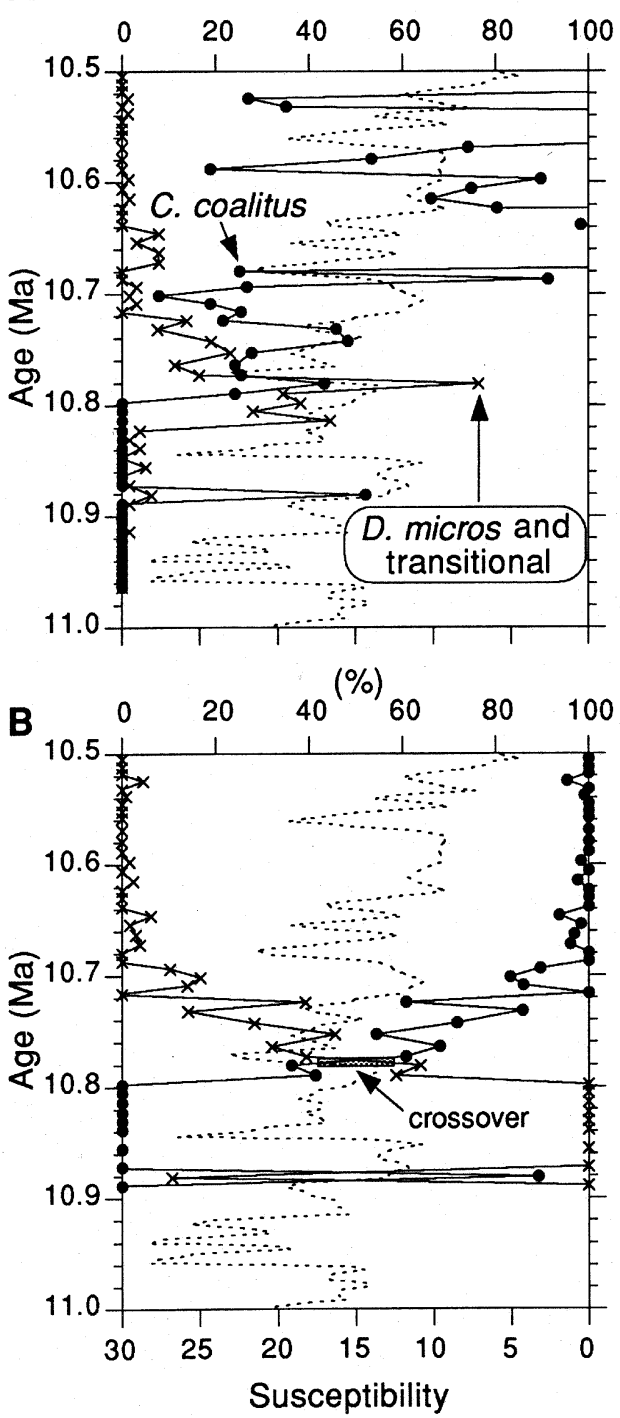

C Specimens $\left(\mathrm{mm}^{-2}\right)$

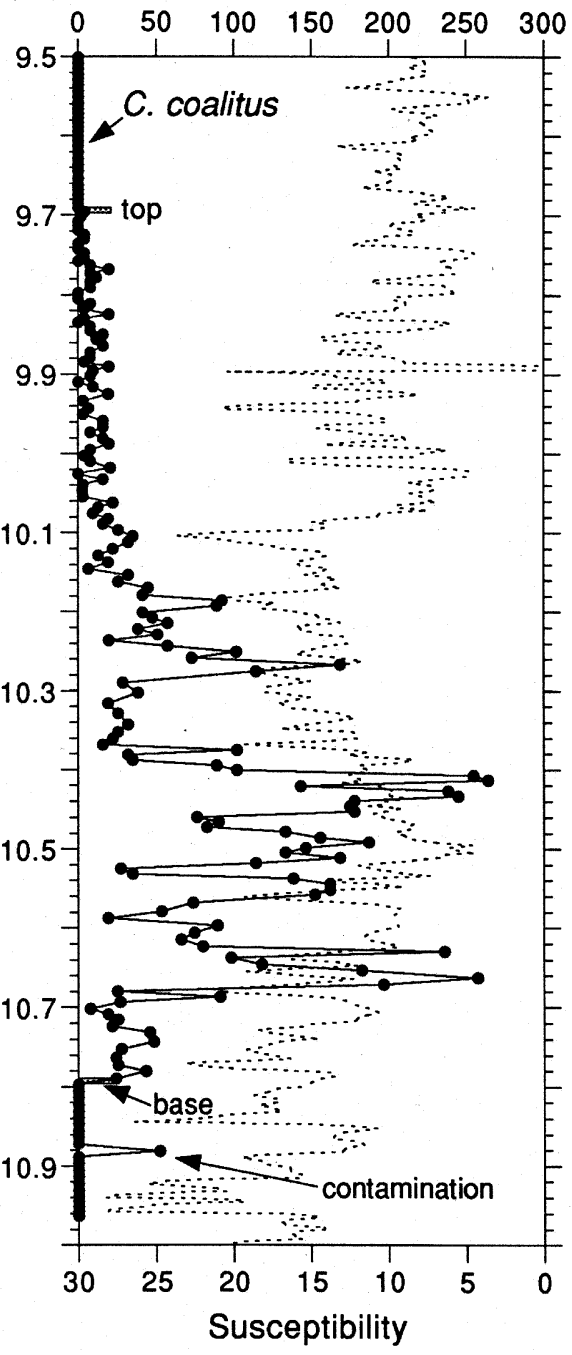

D Specimens $\left(\mathrm{mm}^{-2}\right)$

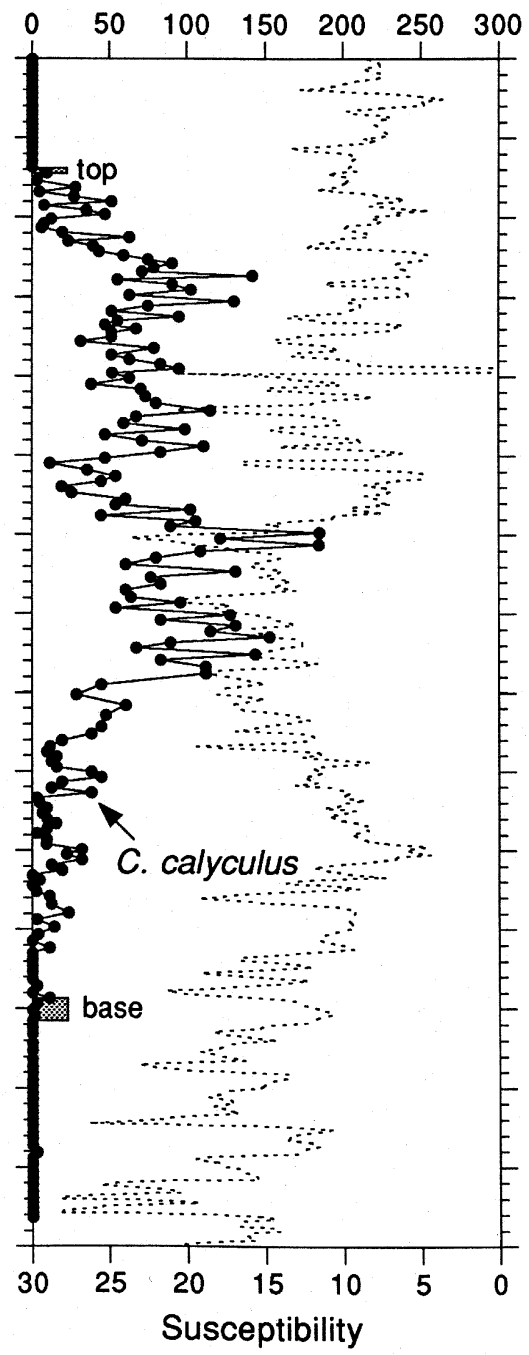

Figure 10. Abundances of Catinaster calyculus (D) and Catinaster coalitus (C). A-B. Basal range abundances of C. coalitus, together with Discoaster micros and transitional forms between D. micros and C. coalitus. See also explanation in Figure 2.

resulting in a downcore sedimentation rate increase at this point instead of a decrease suggested by the orbitally tuned time control (Fig. 18A). Several explanations are possible: (1) inconsistent determinations of the base of $D$. berggrenii caused by taxonomic problems, differences in preservation states (overgrowth) blurring the first occurrence, and/or low, sporadic initial abundances; (2) true diachrony between the western equatorial Atlantic and the eastern equatorial Pacific; (3) huge estimates of the age range of the base of $D$. berggrenii in Leg 138 sediments (Shackleton et al., 1995a), which could have made the resulting median value age estimate used on Leg 154 unrepresentative; and (4) an error in the critical part of the orbital time scale. A combination of explanations 1 and 3 seems probable, although we do not exclude any of these possibilities.

Only one of our events, the top of $C$. miopelagicus, is demonstrably not synchronous between sediments from Legs 154 and 138 .

\section{SEDIMENTATION RATES AND SYNCHRONY}

Deep-sea sedimentation rates are routinely based on biostratigraphy as the single source for age-depth control. The depth uncertainty can be improved through increased sample resolution. The age uncertainty, however, depends both on the accuracy of the age estimate of the biostratigraphic event and its spatial synchrony. Further, sedimentation rates are estimated from age vs. depth plots, either by drawing best-fit lines through all the data over successive depth intervals, or by drawing straight-line segments (uniform rates) between selected datums. The second option, using "best datums," is commonly preferred, yielding intervals of uniform sedimentation rates with 1- to 2-m.y. (or even lower) resolution (Fig. 18A). Increasing the number of accurately dated bioevents per unit time would increase the resolution and results in a better description of the true development of sedimentation rate variations (Fig. 18B). Yet both these plots show that biostratigraphy is a low-resolution tool for sedimentation rate estimates relative to cyclostratigraphic scale resolution.

The immense synchrony problem of biostratigraphic datums was addressed recently in a thought-provoking compilation of biomagnetochronologic deep-sea data by Spencer-Cervato et al. (1994). Of the 124 commonly used Neogene bioevents investigated, only $42 \%$ were recorded at synchronous levels within the set of predefined criteria used (e.g., an average sample resolution of 0.185 m.y.). Despite the fact that any such compilation suffers from variable raw-data quality, 
(\%)

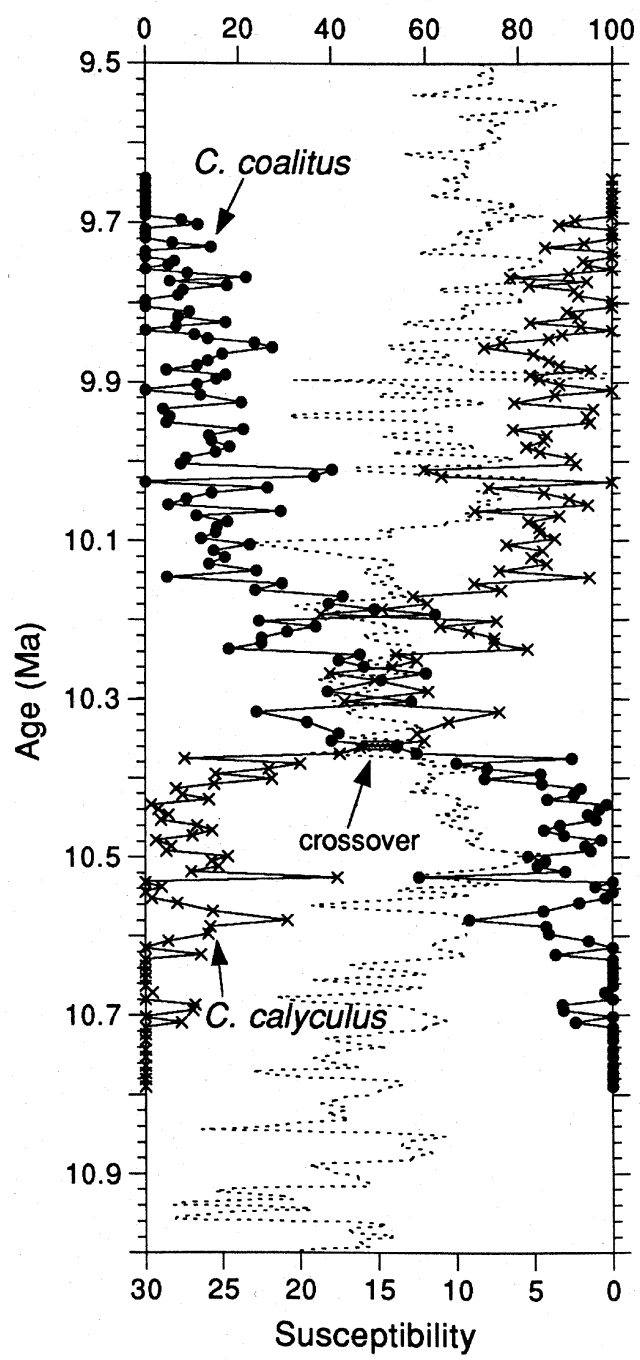

Figure 11. Relative abundances of Catinaster coalitus and Catinaster calyculus, Site 926. See also explanation in Figure 2.

the study by Spencer-Cervato et al. (1994) points both to the importance of understanding ecological preferences of species used in biostratigraphy and to the importance of mapping bioevents from a wide range of environmental settings. Our present contribution can add to that discussion by (1) emphasizing the importance of quantitative approaches to determine the time-dependent abundance behavior of species to improve the understanding of paleoecologic responses of biostratigraphically useful species to variable and changing paleoenvironmental conditions; (2) to emphasize the importance of sample spacing so that the smallest meaningful distance is routinely employed by biostratigraphers, so that sample intervals are close enough to capture the finest details of the records of evolutionary emergence or extinction of species that are preserved in cores; and (3) to calibrate these events to independent chronological tools of highest possible resolution derived from a wide array of different environmental settings.

Moreover, it is evident from the present study, and as pointed out by Spencer-Cervato et al. (1994), that in cases where ancestor-descendant transitions are preserved, these should represent the earliest first occurrences; punctuated speciation events may result from migratory events. Extinctions do not seem to possess any such independent quality control. Furthermore, abundance crossovers and consistent changes in proportions of species (e.g., Thierstein et al., 1977;

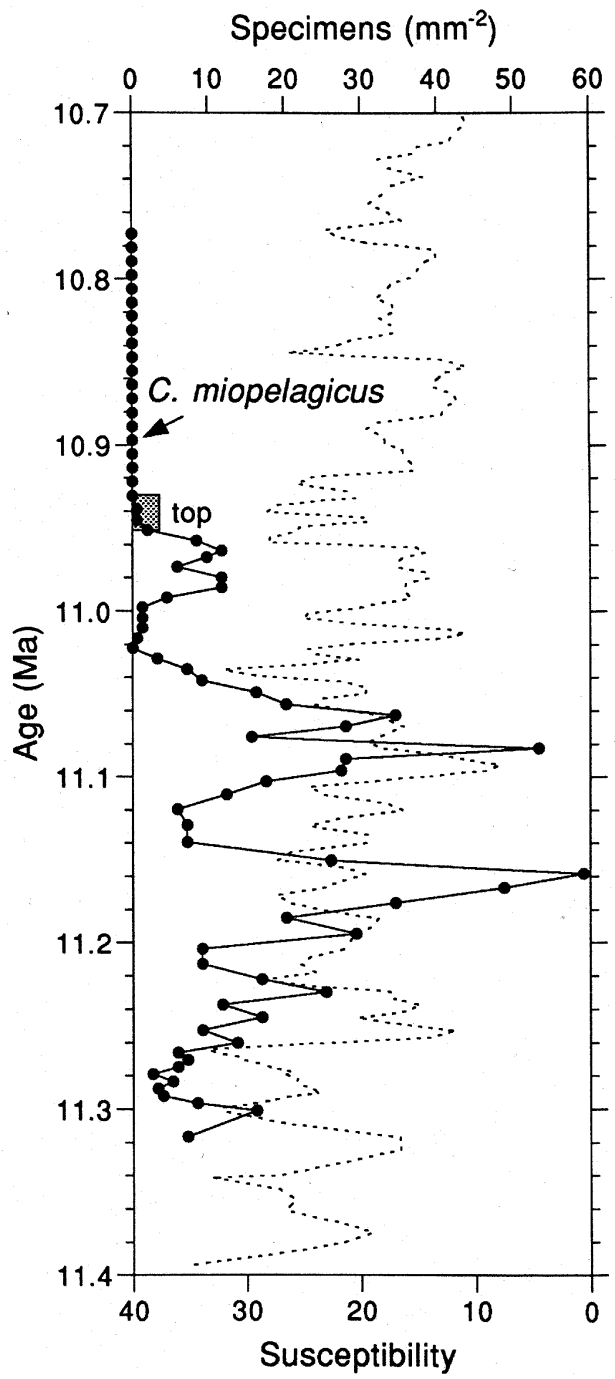

Figure 12. Abundances of Coccolithus miopelagicus, Site 926. See also explanation in Figure 2.

Backman and Shackleton, 1983) represent a class of biostratigraphic events that deserves much further attention. We conclude that much improvement is possible in deep-sea biostratigraphic techniques.

The data were primarily gathered for biostratigraphic purposes. Some of the abundance patterns, however, contain apparent cyclic variations. The most prominent cases are Amaurolithus spp. and A. amplificus, although cyclicity can be discerned also in the patterns of D. hamatus/D. neohamatus and C. coalitus/C. calyculus (Figs. 5-6, 9-10). We have not performed any statistical evaluation of these abundance oscillations. Yet one may speculate that dissolution, productivity, or other paleoecologic fluctuations were among the factors that contributed to the observed patterns. For the time being, however, available data do not permit us to discriminate between the relative contribution of these factors.

\section{ACKNOWLEDGMENTS}

We greatly acknowledge the enthusiastic working atmosphere created on board the JOIDES Resolution by the ship's crew and fellow shipboard scientists during Leg 154 . We extend our thanks to Greg Mountain, chief scientist on the Ceara Rise site survey cruise, who spotted and lyrically described Site 926 as his favorite one. Our study was greatly stimulated by the high-quality time scale data so 


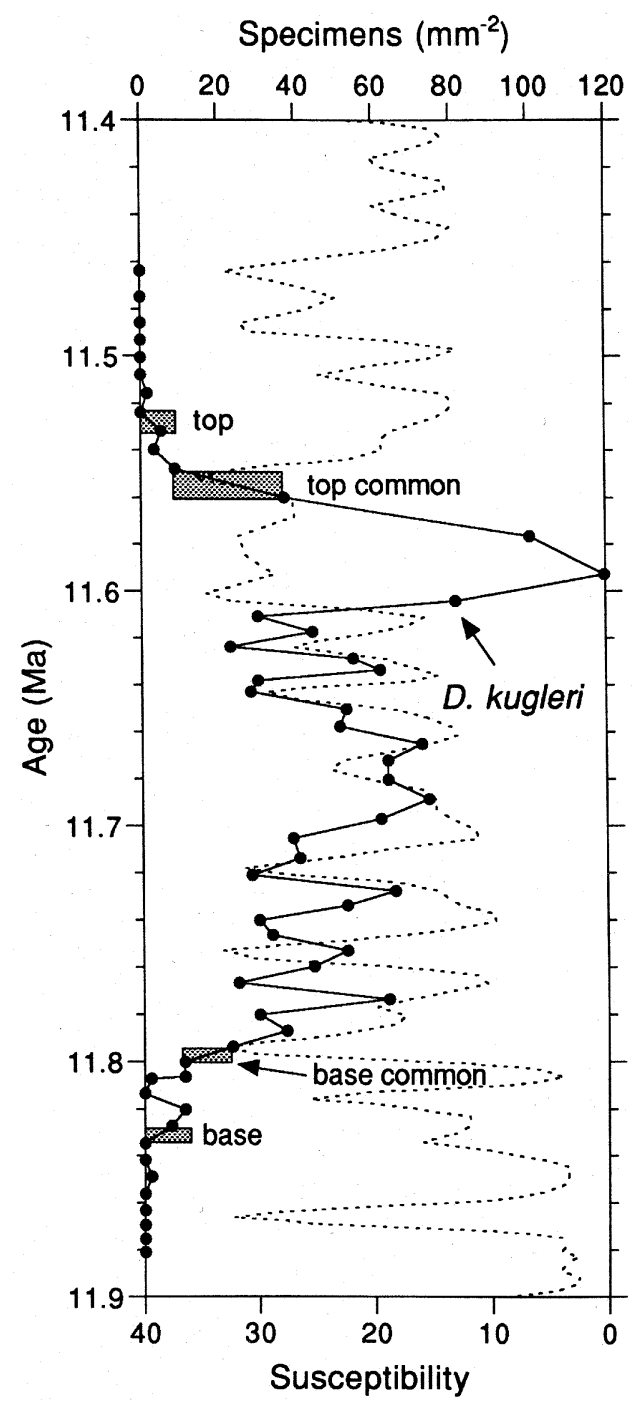

Figure 13. Abundances of Discoaster kugleri, Site 926. See also explanation in Figure 2.

generously provided by Nick Shackleton. We also greatly appreciate the numerous discussions we have had with him about time scales and biostratigraphy. We thank Tim Bralower and Katharina von Salis Perch-Nielsen for helpful reviews, and Bob Wathen for editorial comments, which improved the manuscript. We acknowledge the continuing support from our universities and the Swedish and Italian research councils.

\section{REFERENCES}

Backman, J., Schneider, D.A., Rio, D., and Okada, H., 1990. Neogene lowlatitude magnetostratigraphy from Site 710 and revised age estimates of Miocene nannofossil datum events. In Duncan, R.A., Backman, J., Peterson, L.C., et al., Proc. ODP, Sci. Results, 115: College Station, TX (Ocean Drilling Program), 271-276.

Backman, J., and Shackleton, N.J., 1983. Quantitative biochronology of Pliocene and early Pleistocene calcareous nannofossils from the Atlantic, Indian and Pacific oceans. Mar. Micropaleontol., 8:141-170.

Bolli, H.M., 1966. Zonation of Cretaceous to Pliocene marine sediments based on planktonic foraminifera. Bol. Inf.-Asoc. Venez. Geol., Min. Pet., 9:3-32.

Bramlette, M.N., and Sullivan, F.R., 1961. Coccolithophorids and related nannoplankton of the early Tertiary in California. Micropaleontology, 7:129-188.
Bukry, D., 1971. Coccolith stratigraphy Leg 7, Deep Sea Drilling Project. In Winterer, E.L., Riedel, W.R., et al., Init. Repts. DSDP, 7: Washington (U.S. Govt. Printing Office), 1513-1528.

1973. Low-latitude coccolith biostratigraphic zonation. In Edgar, N.T., Saunders, J.B., et al., Init. Repts. DSDP, 15: Washington (U.S. Govt. Printing Office), 685-703.

1979. Neogene coccolith stratigraphy, Mid-Atlantic Ridge, Deep Sea Drilling Project Leg 45. In Melson, W.G., Rabinowitz, P.D., et al., Init. Repts. DSDP, 45: Washington (U.S. Govt. Printing Office), 307317.

Channell, J.E.T., Rio, D., and Thunell, R.C., 1988. Miocene/Pliocene boundary magnetostratigraphy at Capo Spartivento, Calabria, Italy. Geology, 16:1096-1099.

Chepstow-Lusty, A., 1990. Nannoplankton as indications of climatic variability in the upper Pliocene [Ph.D. thesis]. Cambridge Univ., Cambridge, U.K.

Cita, M.B., 1975. The Miocene/Pliocene boundary: history and definition. In Saito, T., and Burckle, L.H., (Eds.), Late Neogene Epoch Boundaries. Spec. Publ. Micropaleontol., 1-30.

Curry, W.B., Shackleton, N.J., Richter, C., et al., 1995. Proc. ODP, Init. Repts., 154: College Station, TX (Ocean Drilling Program).

Fornaciari, E., Raffi, I., Rio, D., Villa, G., Backman, J., and Olafsson, G., 1990. Quantitative distribution patterns of Oligocene and Miocene calcareous nannofossils from the western equatorial Indian Ocean. In Duncan, R.A., Backman, J., Peterson, L.C., et al., Proc. ODP, Sci. Results, 115: College Station, TX (Ocean Drilling Program), 237-254.

Gard, G., and Backman, J., 1990. Synthesis of arctic and subarctic coccolith biochronology and history of North Atlantic Drift water influx during the last 500,000 years. In Bleil, U., and Thiede, J. (Eds.), The History of the Polar Oceans: Arctic Versus Antarctic: NATO ASI Ser., C308:417-436.

Gartner, S., 1967. Calcareous nannofossils from Neogene of Trinidad, Jamaica, and Gulf of Mexico. Univ. Kansas Paleontol. Contrib., 29:1-7.

- 1992. Miocene nannofossil chronology in the North Atlantic, DSDP Site 608. Mar. Micropaleontol., 18:307-331.

Gartner, S., and Bukry, D., 1975. Morphology and phylogeny of the coccolithophycean family Ceratolithaceae. J. Res. U.S. Geol. Surv., 3:451-465.

Hilgen, F.J., 1991. Extension of the astronomically calibrated (polarity) time scale to the Miocene/Pliocene boundary. Earth Planet. Sci. Lett., 107:349-368.

Hilgen, F.J., Krijgsman, W., Langereis, C.G., Lourens, L.J., Santarelli, A., and Zachariasse, W.J., 1995. Extending the astronomical (polarity) time scale into the Miocene. Earth Planet. Sci. Lett., 136:495-510.

Keigwin, L.D., Jr., 1978. Pliocene closing of the Isthmus of Panama, based on biostratigraphic evidence from nearby Pacific Ocean and Caribbean Sea cores. Geology, 6:630-634.

Kroenke, L.W., Berger, W.H., Janecek, T.R., et al., 1991. Proc. ODP, Init. Repts., 130: College Station, TX (Ocean Drilling Program).

Laskar, J., Joutel, F., and Boudin, F., 1993. Orbital, precessional, and insolation quantities for the Earth from $-20 \mathrm{Myr}$ to $+10 \mathrm{Myr}$. Astron. Astrophys., 270:522-533.

Martini, E., 1971. Standard Tertiary and Quaternary calcareous nannoplankton zonation. In Farinacci, A. (Ed.), Proc. 2nd Int. Conf. Planktonic Microfossils Roma: Rome (Ed. Tecnosci.), 2:739-785.

Maxwell, A.E., Von Herzen, R.P., et al., 1970. Init. Repts. DSDP, 3: Washington (U.S. Govt. Printing Office).

Mayer, L., Pisias, N., Janecek, T., et al., 1992. Proc. ODP, Init. Repts., 138 (Pts. 1 and 2): College Station, TX (Ocean Drilling Program).

Monechi, S., Bleil, U., and Backman, J., 1985. Magnetobiochronology of Late Cretaceous-Paleogene and late Cenozoic pelagic sedimentary sequences from the northwest Pacific, Deep Sea Drilling Project Leg 86, Site 577. In Heath, G.R., Burckle, L.H., et al., Init. Repts. DSDP, 86: Washington (U.S. Govt. Printing Office), 787-797.

Okada, H., and Bukry, D., 1980. Supplementary modification and introduction of code numbers to the low-latitude coccolith biostratigraphic zonation (Bukry, 1973; 1975). Mar. Micropaleontol., 5:321-325.

Olafsson, G., 1991. Late Oligocene through late Miocene calcareous nannofossil biostratigraphy and biochronology [Ph.D. dissert.]. Dept. Geol. Geochem., Stockholm Univ., Stockholm, Sweden.

Perch-Nielsen, K., 1977. Albian to Pleistocene calcareous nannofossils from the western South Atlantic, DSDP Leg 39. In Supko, P.R., Perch-Nielsen, K., et al., Init. Repts. DSDP, 39: Washington (U.S. Govt. Printing Office), 699-823.

Raffi, I., Backman, J., Rio, D., and Shackleton, N.J., 1993. Plio-Pleistocene nannofossil biostratigraphy and calibration to oxygen isotopes stratigra- 
phies from Deep Sea Drilling Project Site 607 and Ocean Drilling Program Site 677. Paleoceanography, 8:387-408.

Raffi, I., and Flores, J.-A., 1995. Pleistocene through Miocene calcareous nannofossils from eastern equatorial Pacific Ocean (Leg 138). In Pisias, N.G., Mayer, L.A., Janecek, T.R., Palmer-Julson, A., and van Andel, T.H. (Eds.), Proc. ODP, Sci. Results, 138: College Station, TX (Ocean Drilling Program), 233-286.

Raffi, I., Rio, D., d'Atri, A., Fornaciari, E., and Rocchetti, S., 1995. Quantitative distribution patterns and biomagnetostratigraphy of middle and late Miocene calcareous nannofossils from equatorial Indian and Pacific oceans (Legs 115, 130, and 138). In Pisias, N.G., Mayer, L.A., Janecek, T.R., Palmer-Julson, A., and van Andel, T.H. (Eds.), Proc. ODP, Sci. Results, 138: College Station, TX (Ocean Drilling Program), 479-502.

Rio, D., Fornaciari, E., and Raffi, I., 1990. Late Oligocene through early Pleistocene calcareous nannofossils from western equatorial Indian Ocean (Leg 115). In Duncan, R.A., Backman, J., Peterson, L.C., et al., Proc. ODP, Sci. Results, 115: College Station, TX (Ocean Drilling Program), 175-235.

Shackleton, N.J., Baldauf, J.G., Flores, J.-A., Iwai, M., Moore, T.C. Jr., Raffi, I., and Vincent, E., 1995a. Biostratigraphic summary for Leg 138. In Pisias, N.G., Mayer, L.A., Janecek, T.R., Palmer-Julson, A., and van Andel, T.H. (Eds.) Proc. ODP, Sci. Results, 138: College Station, TX (Ocean Drilling Program), 517-536.

Shackleton, N.J., Crowhurst, S., Hagelberg, T., Pisias, N.G., and Schneider, D.A., 1995b. A new late Neogene time scale: application to Leg 138 sites. In Pisias, N.G., Mayer, L.A., Janecek, T.R., Palmer-Julson, A., and van Andel, T.H. (Eds.), Proc. ODP, Sci. Results, 138: College Station, TX (Ocean Drilling Program), 73-101.

Spencer-Cervato, C., Thierstein, H.R., Lazarus, D.B., and Beckmann, J.-P., 1994. How synchronous are Neogene marine plankton events? Paleoceanography, 9:739-763.

Stradner, H., 1959. First report on the discoasters of the Tertiary of Austria and their stratigraphic use. Proc. World Petr. Congr., 5th, 1:1081-1095.

Takayama, T., 1993. Notes on Neogene calcareous nannofossil biostratigraphy of the Ontong Java Plateau and size variations of Reticulofenestra coccoliths. In Berger, W.H., Kroenke, L.W., Mayer, L.A., et al., Proc. ODP, Sci. Results, 130: College Station, TX (Ocean Drilling Program), 179-229.

Theodoridis, S., 1984. Calcareous nannofossil biozonation of the Miocene and revision of the helicoliths and discoasters. Utrecht Micropaleontol. Bull., 32:1-271.

Thierstein, H.R., Geitzenauer, K., Molfino, B., and Shackleton, N.J., 1977. Global synchroneity of late Quaternary coccolith datum levels: validation by oxygen isotopes. Geology, 5:400-404.

\section{Date of initial receipt: 11 December 1995 \\ Date of acceptance: 15 April 1996 \\ Ms 154SR-101}

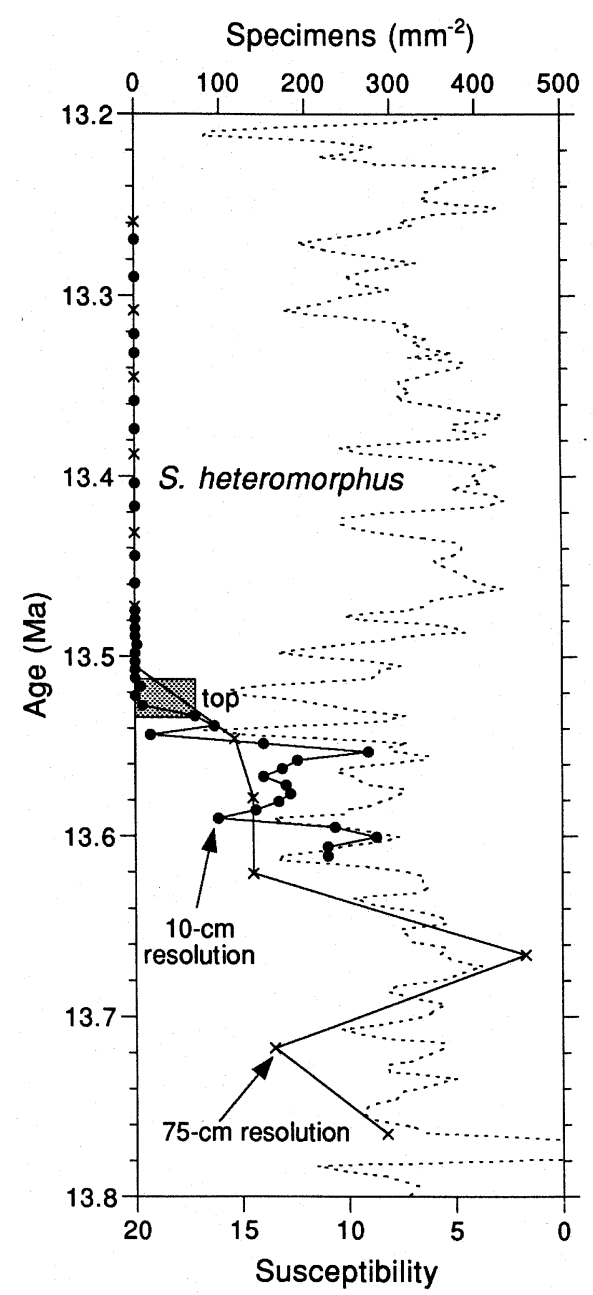

Figure 14. Abundances of Sphenolithus heteromorphus, Site 926. See also explanation in Figure 2. 


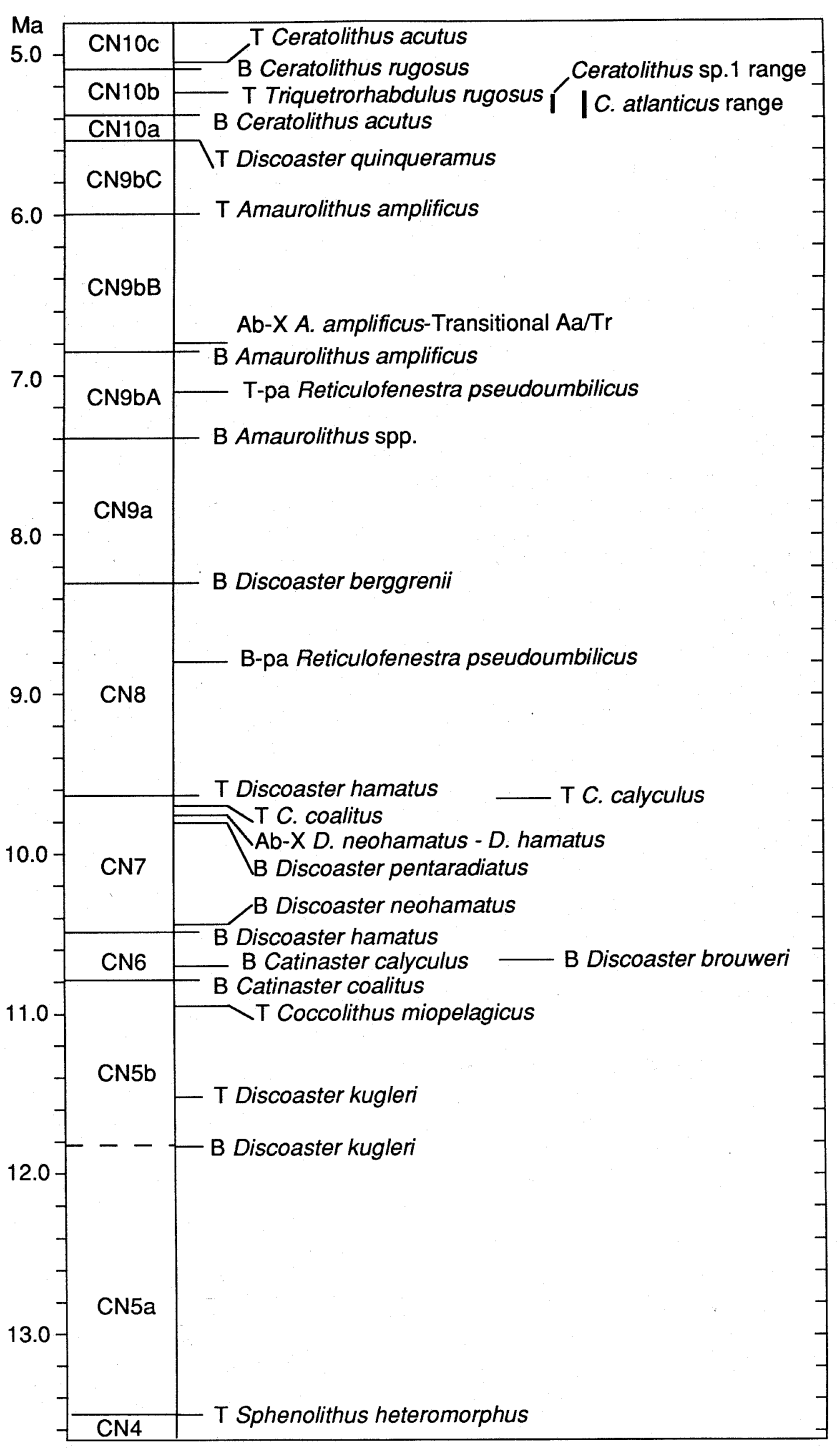

Figure 15. Summary of biostratigraphy in Site 926. Events discussed in this study, their age assignments (Table 1), and the zonal system of Okada and Bukry (1980) are shown. $\mathrm{T}=$ top, $\mathrm{B}=$ base, $\mathrm{Ab}-\mathrm{X}=$ abundance crossover, $\mathrm{T}-\mathrm{pa}=$ top paracme, $\mathrm{B}-\mathrm{pa}=$ base paracme, transitional Aa/Tr $=\operatorname{transitional}$ between $A$. amplificus and T. rugosus. 


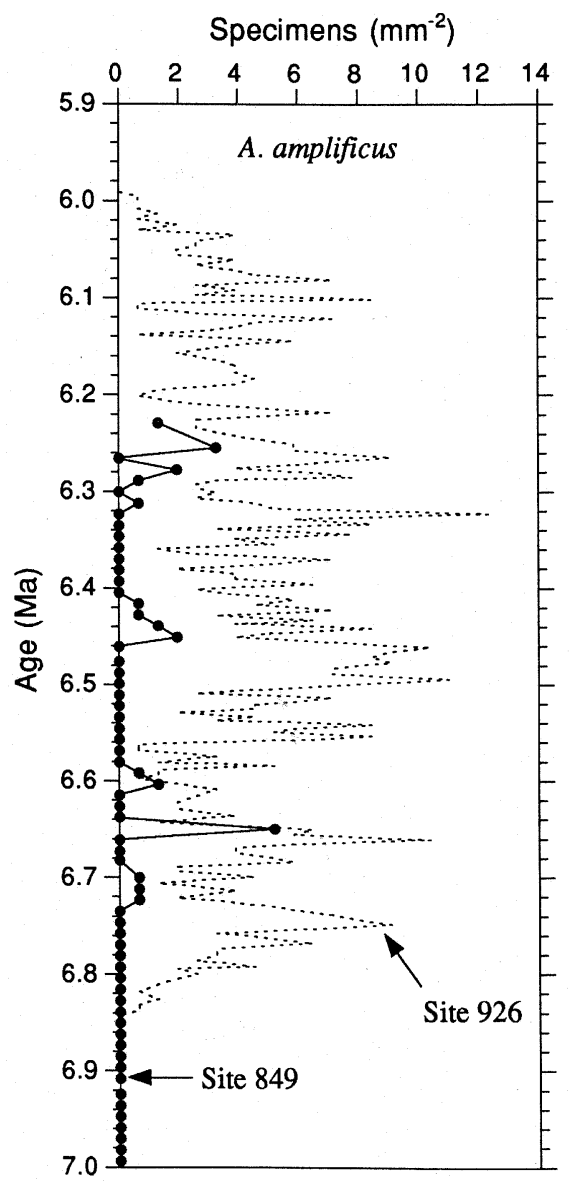

Figure 16. Comparison of abundances of Amaurolithus amplificus at eastern equatorial Pacific Site 849 and western equatorial Atlantic Site 926. The age model for Site 849 represents a linear interpolation between the top of Discoaster quinqueramus and the base of Amaurolithus spp., using age estimates from this study.

Figure 17. A. Relative abundances of Triquetrorhabdulus rugosus and transitional forms between Amaurolithus amplificus and T. rugosus, applying the Leg 154 shipboard time scale (= Leg 138 time scale), Site 853. B. Relative abundances of $T$. rugosus and transitional forms between A. amplificus and T. rugosus, applying the orbitally tuned time scale of Hilgen et al. (1995) for the reversal boundaries of Chron C3A.n2, Site 853. C. Relative abundances of $T$. rugosus and transitional forms between A. amplificus and T. rugosus, applying the orbitally tuned time scale of Shackleton and Crowhurst (this volume), Site 926.
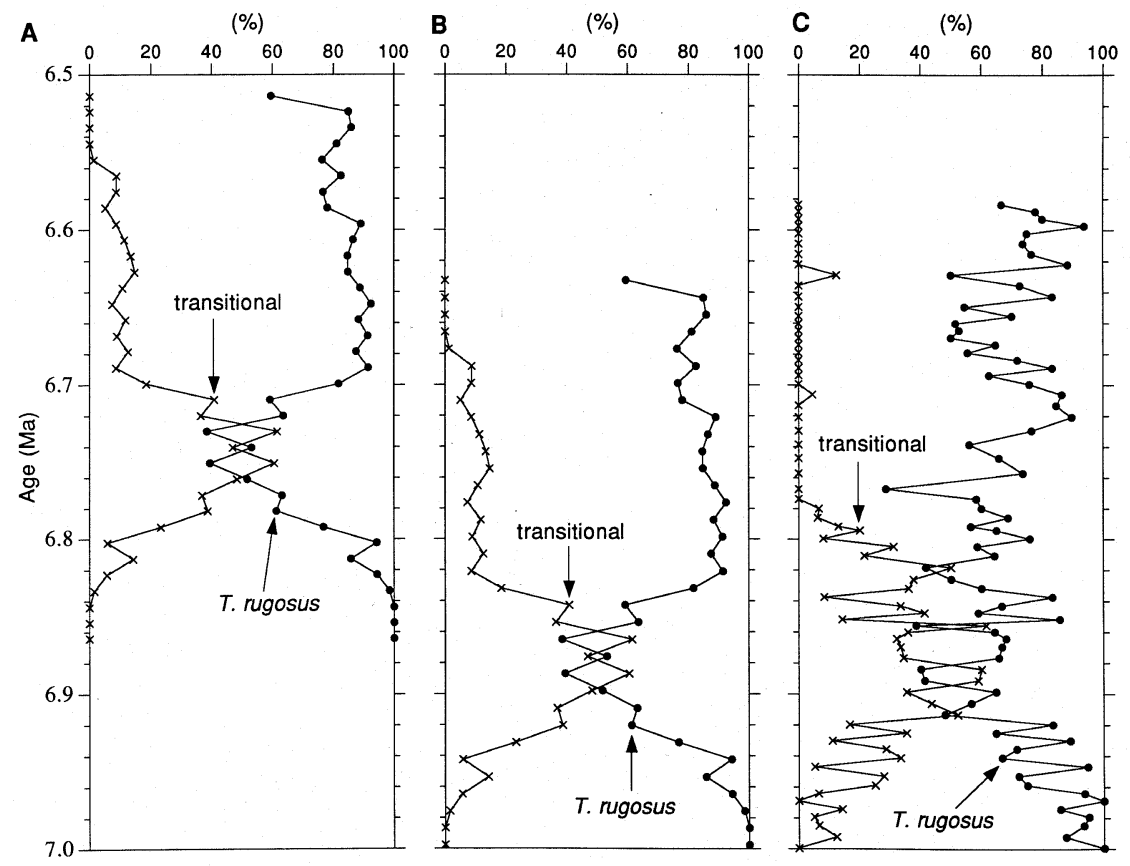
A Sedimentation rate (mcd/m.y.)

B Sedimentation rate (mcd/m.y.)
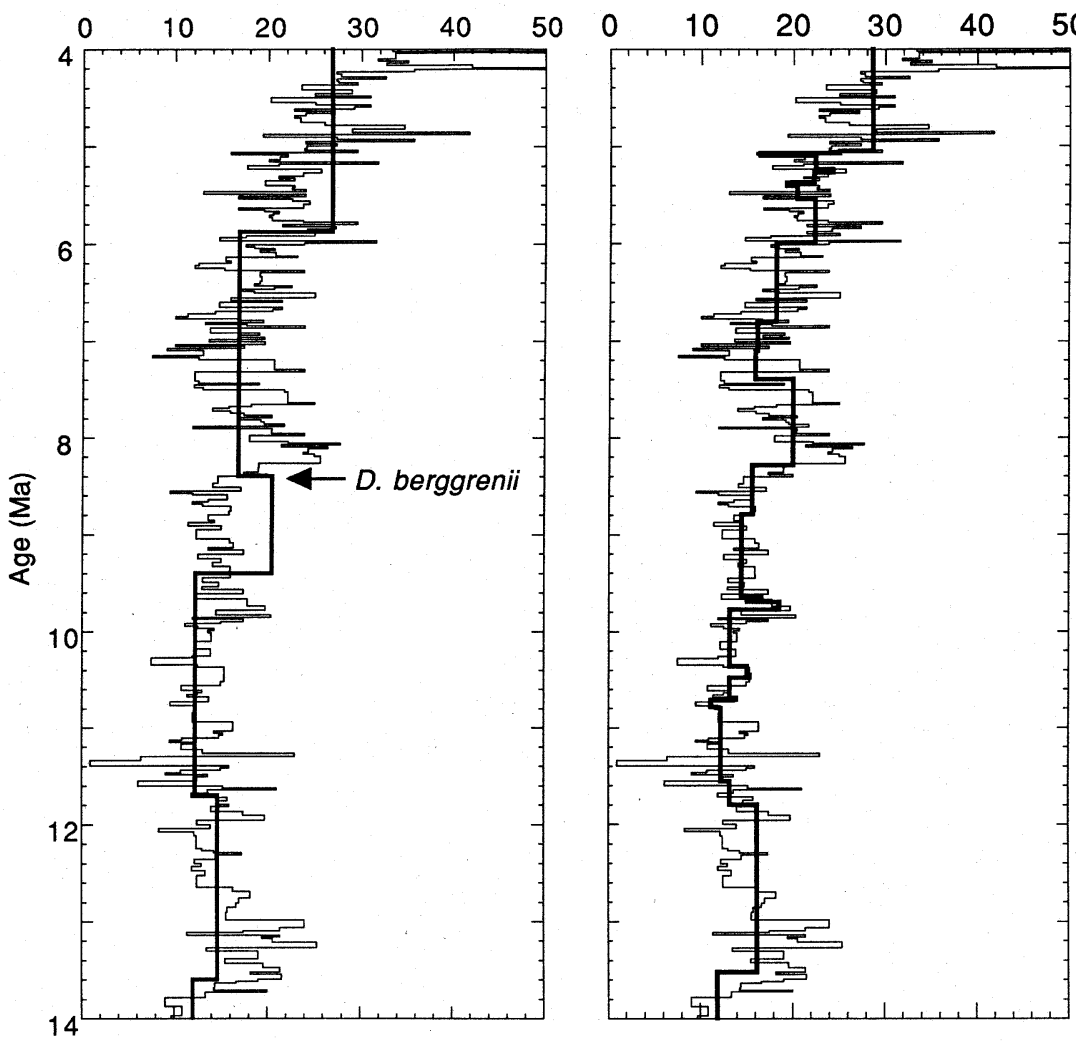

\section{0}

Figure 18. Sedimentation rates plotted vs. age, Site 926. Rates derived from orbitally tuned control points (thin line) and biostratigraphy (thick line) are shown. A. Resolution of the biostratigraphy-derived rates as determined aboard ship. B. Biostratigraphic resolution of the present study. The base of $D$. berggrenii is pointed out. 